\title{
Review
}

\section{The adrenergic stress response in fish: control of catecholamine storage and release}

\author{
Stephen G. Reid *, Nicholas J. Bernier, Steve F. Perry \\ Department of Biology, University of Ottawa, 30 Marie Curie, Ottawa, Ontario K1N 6N5, Canada
}

Received 8 August 1997; received in revised form 23 December 1997; accepted 20 January 1998

Communicated by Dr. P. W. Hochachka, Editor

\begin{abstract}
In fish, the catecholamine hormones adrenaline and noradrenaline are released into the circulation, from chromaffin cells, during numerous 'stressful' situations. The physiological and biochemical actions of these hormones (the efferent adrenergic response) have been the focus of numerous investigations over the past several decades. However, until recently, few studies have examined aspects involved in controlling/modulating catecholamine storage and release in fish. This review provides a detailed account of the afferent limb of the adrenergic response in fish, from the biosynthesis of catecholamines to the exocytotic release of these hormones from the chromaffin cells. The emphasis is on three particular topics: (1) catecholamine biosynthesis and storage within the chromaffin cells including the different types of chromaffin cells and their varying arrangement amongst species; (2) situations eliciting the secretion of catecholamines (e.g. hypoxia, hypercapnia, chasing); (3) cholinergic and non-cholinergic (i.e. serotonin, adrenocorticotropic hormone, angiotensin, adenosine) control of catecholamine secretion. As such, this review will demonstrate that the control of catecholamine storage and release in fish chromaffin cells is a complex processes involving regulation via numerous hormones, neurotransmitters and second messenger systems. (C) 1998 Elsevier Science Inc. All rights reserved.
\end{abstract}

Keywords: Adrenaline; Catecholamines; Cholinergic release; Chromaffin cells; Fish; Non-cholinergic release; Noradrenaline; Stress

\section{Introduction}

The catecholamine hormones, adrenaline and noradrenaline, are released from chromaffin cells, into the circulation of fish, during exposure to a wide range of internal and environmental stressors [176,201,202,251]. Once in the circulation, these hormones function to diminish the plethora of detrimental consequences often associated with stressful situations. In particular, one of the primary roles of plasma catecholamines is to modulate cardiovascular and respiratory function in order to maintain adequate levels of oxygen in the blood and, therefore, a sufficient supply to the tissues. In addition,

\footnotetext{
* Corresponding author. Present address: Department of Biology, McMaster University, 1280 Main St. W., Hamilton, Ontario, L8S 4K1, Canada. Tel.: + 1905 5259140, ext. 27412; fax: + 1905 5226066; e-mail: reidsg@mcmail.mcmaster.ca
}

these biogenic amines serve to mobilize energy stores to provide for the increased energy demands that often accompany stress [231,235]. Given the multitude of effects exerted by these hormones, both the physiological and biochemical consequences of an elevation of plasma catecholamines have formed an extensive field of investigation by fish physiologists and biochemists over the past several decades. However, equally important to the general understanding of the physiology of catecholamines are the mechanisms underlying their release from the chromaffin cells into the circulation. In comparison with the literature regarding the consequences of catecholamine release, little is known about the release process of these hormones in fish. On the other hand, the control of catecholamine release is an area of extensive study in mammalian physiology (see reviews from the Symposium on the Adrenal Gland; 
$[39,75,144,167,217,250,254,273,277,293])$. Indeed, in mammals, the chromaffin cell is an important model used in the study of secretion and exocytosis. As such, the goals of this review are to provide a detailed account of the afferent limb of the adrenergic stress response from catecholamine biosynthesis and storage through events culminating in the secretion of catecholamines from the chromaffin cells, into the circulation.

\section{Storage of catecholamines}

\subsection{Catecholamine biosynthesis}

Catecholamines, adrenaline and noradrenaline, are synthesized, within the chromaffin cell, via the Blaschko pathway beginning with the amino acid precursor tyrosine $[30,122]$. Both the catecholamine biosynthetic pathway and the metabolic processes resulting in their degradation, in fish, have recently been reviewed [235]. In this current paper, a general account of catecholamine biosynthesis is discussed in addition to a variety of factors that have been implicated in modulating biosynthesis in various vertebrate species. The initial step in biosynthesis is the hydroxylation of tyrosine by the enzyme tyrosine hydroxylase $(\mathrm{TH})$ to form L-dihydroxyphenylalanine (L-DOPA) in the rate-limiting step in the synthesis of noradrenaline. Tyrosine hydroxylase has an absolute requirement for both $\mathrm{Fe}^{2+}$ and molecular oxygen while tetrahydropteridine serves as a cofactor. In the Atlantic cod (Gadus morhua), the $\mathrm{pH}$ and temperature optima of this enzyme are 6.0 and $30-35^{\circ} \mathrm{C}$, respectively [136].

A variety of factors are capable of regulating the activity of TH in various vertebrate species [131]. First, TH activity is subject to end-product inhibition by dopamine and noradrenaline suggesting a rapid and specific control of the rate of catecholamine biosynthesis in vivo [255]. Additionally, a variety of neuronal and hormonal factors are capable of increasing the activity of TH. Some of these include, increased nervous stimulation of the chromaffin cells [185,186,264,265], adrenocorticotropic hormone (ACTH) within the blood [187], nicotine [119,258] and glucocorticoids [258]. Additionally, a variety of neuropeptides including vasoactive intestinal polypeptide (VIP), pituitary adenylyl cyclase activating polypeptide (PACAP), secretin and angiotensin $[285,290,308]$ have all been demonstrated to influence $\mathrm{TH}$ activity.

The second step in catecholamine biosynthesis involves the enzyme L-aromatic amino acid decarboxylase (AADC, or DOPA decarboxylase) which decarboxylates L-DOPA to form dopamine. This enzyme has a broad substrate affinity and specificity and is present in sufficient quantities that L-DOPA does not accumulate to any substantial extent [122]. AADC requires pyridoxal-5-phosphate as a cofactor and can be inhibited by compounds structurally similar to L-DOPA, such as $\alpha$-methyldopa and $N$-methylmelaimide [179].

The hydroxylation and decarboxylation reactions catalyzed by TH and AADC, respectively, both occur within the cytosol. The end product of the AADC reaction, dopamine, is then transported into secretory vesicles (granules) where the enzyme dopamine- $\beta$-hydroxylase $(\mathrm{D} \beta \mathrm{H})$ converts it into noradrenaline via a side chain hydroxylation. $\mathrm{D} \beta \mathrm{H}$, a copper-containing tetrameric glycoprotein, requires both molecular oxygen and ascorbic acid as cofactors. $\mathrm{D} \beta \mathrm{H}$ is present in secretory granules in both a membrane bound form and a soluble form [135], the ratio of which differs amongst species [63]. A portion of the soluble fraction of $\mathrm{D} \beta \mathrm{H}$ may be released, together with the catecholamines, ATP and chromogranins, during exocytosis [37]. The temperature optima for $\mathrm{D} \beta \mathrm{H}$ in the dogfish and Atlantic cod are $24.5-32$ and $27^{\circ} \mathrm{C}$, respectively while the $\mathrm{pH}$ optima are 5.4-6.2 and 5.4, respectively [132,134].

The activity of $\mathrm{D} \beta \mathrm{H}$ in fish chromaffin tissue has been documented in numerous studies of a variety of fish species including Atlantic cod, Gadus morhua [134], spotted gar, Lepisosteus platyrhincus [6], African lungfish, Protopterus aethiopicus [4], two elasmobranchs, Squalus acanthias and Etmopterus spinax [132] and the Atlantic hagfish, Myxine glutinosa [133]. Most tissues, in mammals, possess endogenous inhibitors of $\mathrm{D} \beta \mathrm{H}$, such as sulfhydryl compounds, that form complexes with the $\mathrm{Cu}^{2+}$ at the active site of the enzyme. These inhibitors can be inactivated by the addition of $\mathrm{Cu}^{2+}$ or $N$-ethylmaleimide, a sulfhydryl blocker, a necessary procedure when measuring the in vitro activity of this enzyme [24]. Like tyrosine hydroxylase, $\mathrm{D} \beta \mathrm{H}$ in mammals is also subject to neuronal regulation where increased nervous stimulation of the chromaffin cell results in an increase in $\mathrm{D} \beta \mathrm{H}$ activity [55]. Additionally, hormonal regulation of $\mathrm{D} \beta \mathrm{H}$ via adrenocorticotropic hormone and glucocorticoids also functions to modulate the activity of this enzyme [289].

In some chromaffin cells (see Section 2.2), noradrenaline is transported from the secretory vesicle, into the cytoplasm, where it is methylated to form adrenaline by the enzyme phenylethanolamine- $N$ methyltransferase (PNMT). It is not known how noradrenaline is made available to cytoplasmic PNMT nor how, once synthesized in the cytosol, adrenaline is transported into the storage vesicles. Alternately, once synthesized, noradrenaline may remain stored within the secretory granules. PNMT activity has also been measured in a variety of fish species including the Atlantic hagfish, M. glutinosa [133], the spotted gar, L. platyrhincus [6], the African lungfish, Rotopterus aethiopicus [4], the rainbow trout, Oncorhynchus mykiss [175,241], the Atlantic cod, G. morhua [3,7] and the 
dogfish, S. acanthias [2]. A comparison of optimal activities of $\mathrm{TH}, \mathrm{D} \beta \mathrm{H}$ and PNMT suggests that the conversion of noradrenaline to adrenaline (PNMT reaction) is the rate-limiting step in adrenaline formation [131].

PNMT is inhibited by its end product adrenaline, and to a lesser extent by noradrenaline [95-97]. Furthermore, the inhibition occurs at concentrations of adrenaline and/or noradrenaline normally present in adrenal medullary chromaffin cells suggesting a specific physiological role, particularly for adrenaline, in regulating PNMT activity. As with $\mathrm{TH}$ and $\mathrm{D} \beta \mathrm{H}$, both nervous (cholinergic) stimulation of chromaffin cells [84] and glucocorticoids [248,291,300,301] have been demonstrated to influence PNMT activity in mammals. However, modulation of PNMT activity by glucocorticoids does not appear to occur in fish or other lower vertebrates (see Section 2.5).

\subsection{Arrangement of chromaffin cells}

Chromaffin cells originate embryologically from the neural crest $[58,62,160]$, and derive their name from the granulated brownish-yellow appearance, produced by the oxidation of intracellular catechols or indolamines, following staining with chromate and/or dichromate $[58,147]$. The arrangement of the catecholamine-containing chromaffin cells differs across the entire vertebrate lineage. In mammals, chromaffin cells are found within the adrenal gland, specifically the adrenal medulla, surrounded by the adrenal cortex that contains the steroidogenic interrenal cells $[60,62,201]$. In birds, chromaffin cells are also located within the adrenal gland but, in avian species, there is no division into medulla or cortex and the chromaffin and interrenal cells are intermingled [58,114]. Chromaffin cells in reptiles form a similar arrangement to those in birds [298,299]. In urodele amphibians, chromaffin cells are located within segmented bodies associated with sympathetic nerves on the ventral side of the kidney whilst, in anurans, chromaffin cells form a distinct mass on the surface of the kidney $[8-13,58,60,108,109]$.

Amongst different classes of fish, the arrangement of chromaffin cells also exhibits substantial diversity. In evolutionary terms, the cyclostomes/agnathans (i.e. hagfish and lampreys) represent the most primitive group of fish. In these fish, the chromaffin cells are distributed within the systemic and portal hearts $[15,32,33,130,212,213,281]$ and in large veins and arteries $[15,127,128]$. Elasmobranchs represent a more advanced evolutionary stage than the cyclostomes and, in this group, the chromaffin cells are associated with paravertebral autonomic ganglia $[2,170,252,253,281]$. The axillary bodies, comprising chromaffin cells in association with the gastric ganglia, are the primary source of circulating catecholamines in these fish [201,202]. In dipnoans (e.g. Lepidosiren and Protopterus) chromaffin cells are distributed in the intercostal arteries [121], the left posterior cardinal vein $[19,105]$ and the atrium $[4,19,53,249,250]$.

The most evolutionary advanced fish are represented by the teleosts. Initial descriptions of the chromaffin cell, in teleosts, as the homologue of the adrenal gland, were documented in the early 20 th century $([103,104,106,107]$, also see review [58]). In teleost fish, the chromaffin cells are located within the walls of the posterior cardinal vein $(\mathrm{PCV})$ and in close association with the lymphoid tissue of the kidneys, particularly in the anterior region of the kidney ('head kidney') ([100,115,172,173,201,202,238, 239,305]; Fig. 1A, B). In general, chromaffin cells are often observed either singly or clustered into groups of several cells. The association of chromaffin cells with the steroidogenic interrenal cells may vary amongst different teleost species [58,189].

\subsection{Different chromaffin cell types}

The primary circulating catecholamines in fish are adrenaline and noradrenaline with only a few studies having measured levels of circulating dopamine $[42,78,79,115]$. A variety of studies have demonstrated that adrenaline and noradrenaline are stored, at least in part, in separate populations of chromaffin cells.

The presence of both noradrenaline- and adrenalinecontaining chromaffin cells within the posterior cardinal vein and head kidney has been demonstrated in the freshwater cyprinid, Scardinius erythrophthlamus [172]. The two different cell types were distinguished on the basis of light microscopy studies and of morphological characteristics at the electron microscope level. Noradrenaline-containing cells had strongly electron-dense secretory granules $[59,61]$ that were generally spherical in shape. The enhanced electron density of noradrenaline containing granules arises from the precipitation of noradrenaline following fixation with glutaraldehyde. Adrenaline, on the other hand, remains soluble following glutaraldehyde fixation such that, following postfixation staining with dichromate, noradrenalinecontaining cells appear more electron dense than adrenaline-containing cells. Granules within the noradrenaline-containing cells were spherical in appearance (average diameter $200 \mathrm{~nm}$ ) and distributed evenly throughout the cell with the exception of the region of the nucleus. In the adrenaline-containing cells, granules were spherical or elongated (diameter $30 \mathrm{~nm}$ ), and also were distributed homogeneously throughout the cell [172]. Other cell types were observed which had a density midway between the noradrenaline- and adrenaline-containing cells and in some cells the granules appeared empty. These later cell types may represent a different stage of chromaffin cell development or contain amines other than the catecholamines. 

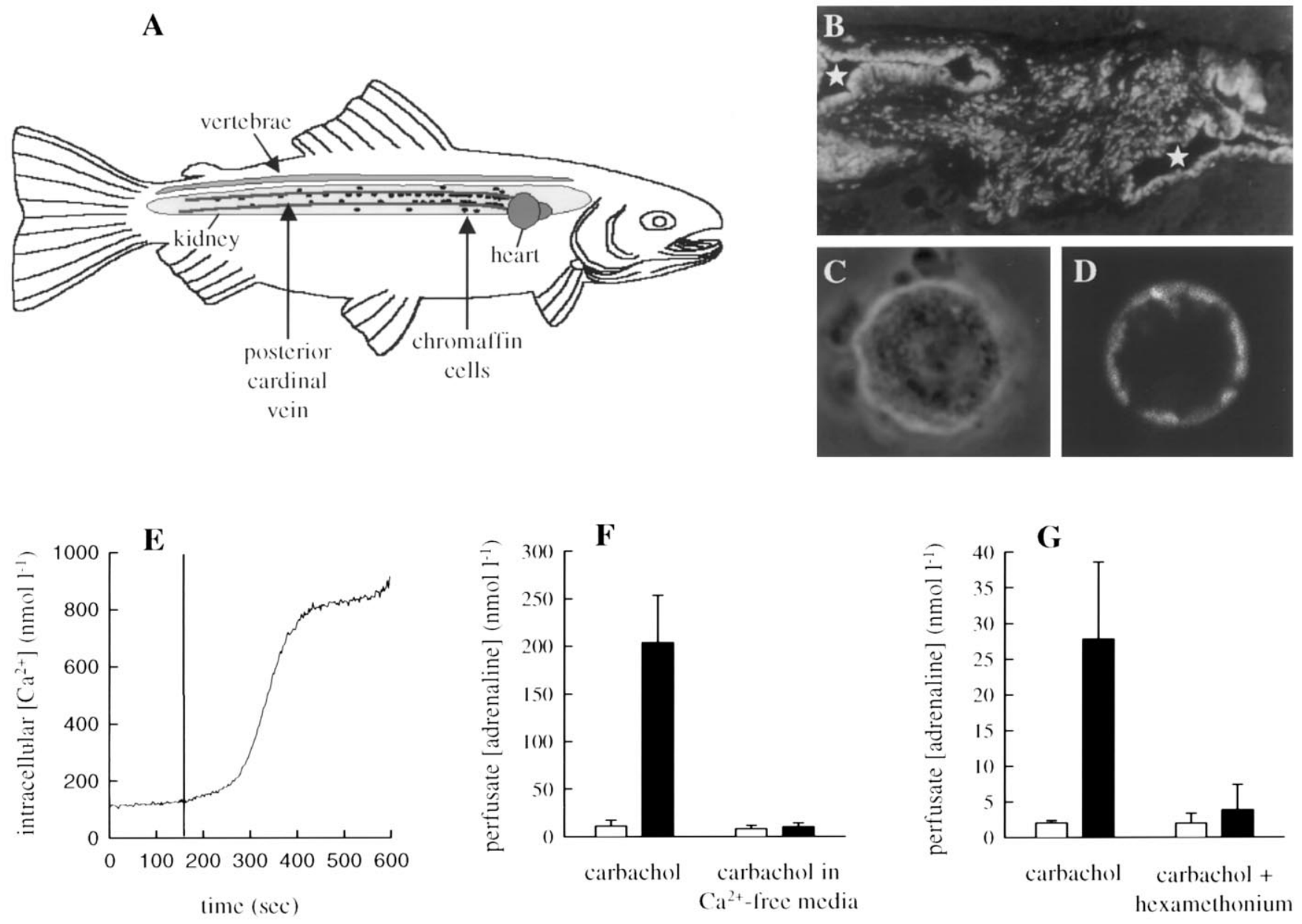

Fig. 1. The location, appearance and pharmacological properties of teleost fish chromaffin cells. (A) Chromaffin cells in teleost fish (a rainbow trout in the schematic) are located in the head kidney region within the walls of the posterior cardinal vein as it runs through the kidney to the heart. (B) A sagittal section through the head kidney/posterior cardinal vein in the Atlantic cod, G. morhua (magnification $\times 90)$. An asterisk (*) denotes the lumen of the PCV. Chromaffin cells are labeled (white) with a fluorescent antibody raised against dopamine- $\beta$-hydroxylase, the enzyme that converts dopamine into noradrenaline. (C) A phase contrast view of an individual chromaffin cell (magnification $\times 2000$ ). Note the granular appearance of the cell indicative of secretory granules. (D) Labeling of nicotinic cholinoceptors on a single chromaffin cell with fluorescently-tagged $\alpha$-bungarotoxin (magnification $\times 2000$ ). E) The temporal changes in intracellular $\mathrm{Ca}^{2+}$ concentration $\left[\mathrm{Ca}^{2+}\right]$ in a single rainbow trout chromaffin cell after the addition of nicotine (at the vertical line). (F) The release of adrenaline, in situ, in response to the mixed muscarinic/nicotinic agonist carbachol carbamylcholine is abolished in $\mathrm{Ca}^{2+}$-free media (data from rainbow trout). Open bars indicate perfusate adrenaline levels prior to the addition of carbachol; solid bars represent values after carbachol addition. (G) Pre-treatment with the ganglionic blocker hexamethonium, to block nicotinic receptors, also eliminates carbachol-evoked catecholamine release (data from the American eel, see text for eel-trout differences). Open bars indicate perfusate adrenaline levels prior to the addition of carbachol; solid bars represent values after carbachol addition.

The presence of these two cell types has also been demonstrated in the head kidney of the stickleback, Gasterosteus aculeatus [100] and the carp, Cyprinus carpia [174]. In the Holostean fish, Amia calva, [307] only one population of secretory granules was observed based on electron-density, and as such, it was not possible to distinguish between adrenaline- and noradrenaline-containing cells in this species.

Utilizing light and electron microscopy, the presence of both noradrenaline- and adrenaline-containing chromaffin cells has been demonstrated in the rainbow trout [173]. Additionally, other immunohistochemical studies have revealed the presence of separate noradrenaline and dopamine containing cells in the sea bass, Dicentrarchus labrax (L.) [1] and the American eel, Anguilla rostrata [117]. Recently, positive labeling reactions for antisera raised against tyrosine hydroxylase (TH) and dopamine- $\beta$-hydroxylase $(\mathrm{D} \beta \mathrm{H})$ have been observed in the rainbow trout, Atlantic cod (Fig. 1B) and European eel chromaffin cell [237]. Of these TH- and $\mathrm{D} \beta \mathrm{H}$-positive cells, a sub-population also exhibited a positive labeling reaction for PNMT, the enzyme which catalyses the methylation of noradrenaline into adrenaline. This sub-population of PNMT-positive cells were considered to be adrenaline-containing cells whereas those which exhibited a positive labeling reaction for $\mathrm{TH}$ and 
Table 1

The levels of adrenaline and noradrenaline ( $\mu \mathrm{g} \mathrm{g}^{-1}$ tissue weight) stored within the chromaffin tissue of various species of fish (cyclostomes, dipnoans, elasmobrachs, ganoids and teleosts).

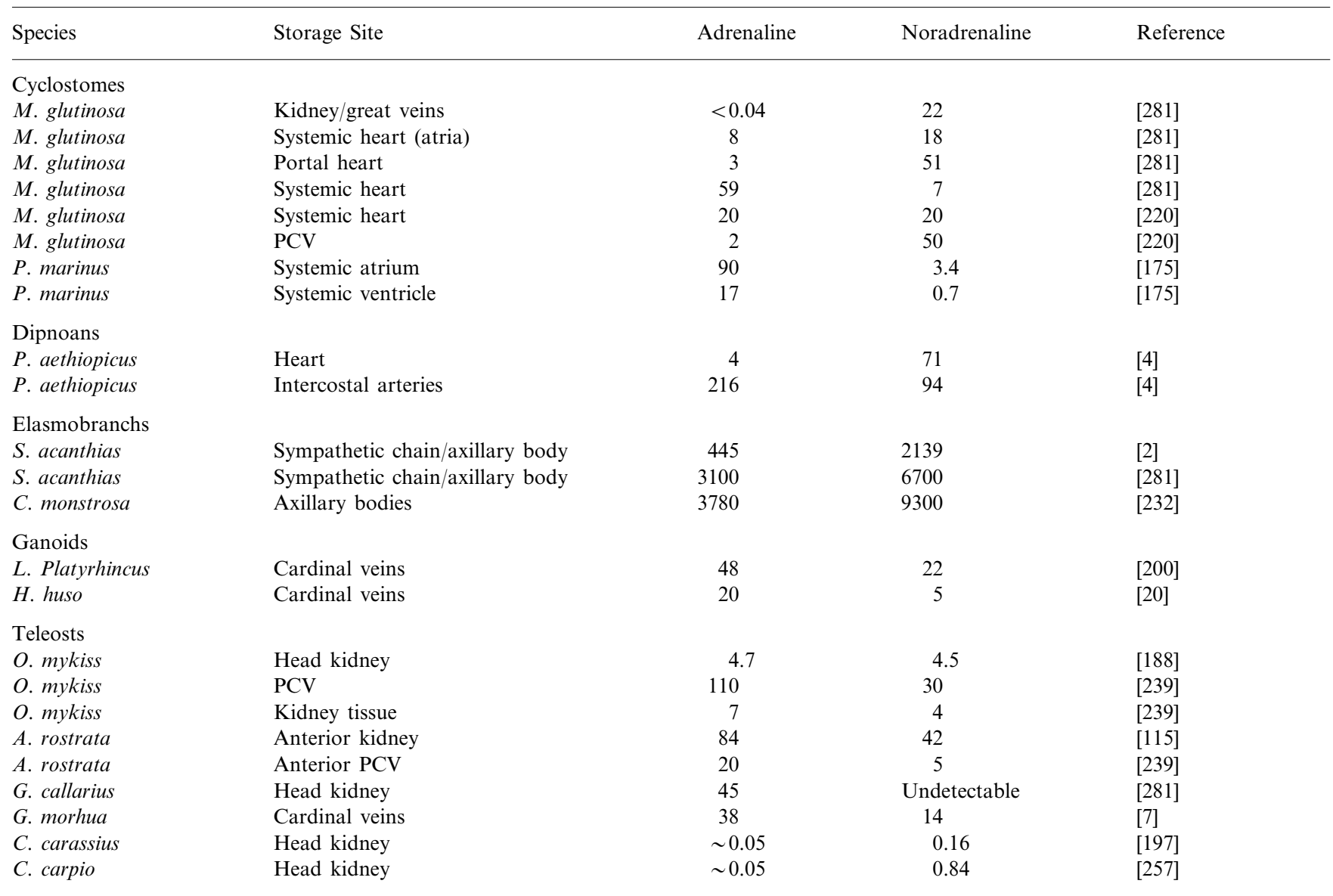

The particular region of tissue storage site (examined in each study reference) is indicated in the table. PCV, posterior cardinal vein. See text for additional details.

$\mathrm{D} \beta \mathrm{H}$, but not PNMT, were considered to be noradrenaline containing cells. Anecdotally, this phenomenon was more pronounced in cod and trout then in the eel [237].

Also in the rainbow trout, the differential release of adrenaline, over noradrenaline, in response to stimulation with a cholinergic agonist has been demonstrated utilizing an in situ saline-perfused posterior cardinal vein preparation [239]. In this preparation, perfusion with $60 \mathrm{mmol} 1^{-1} \mathrm{~K}^{+}$, a non-specific depolarizing stimuli, caused the exocytotic release of catecholamines by directly altering membrane potential without the intervention of receptors or receptor-coupled second messenger systems [37]. Perfusion with $60 \mathrm{mmol} \mathrm{1}^{-1}$ $\mathrm{K}^{+}$did not alter the adrenaline:noradrenaline ratio in the perfusate, compared with ratio prior to stimulation. However, the application of the acetylcholine agonist, carbamylcholine (carbachol, $10^{-8}-2 \times 10^{-7} \mathrm{~mol}$ ) caused the adrenaline:noradrenaline ratio to increase from approximately 1 to $4-8$. This preferential release of adrenaline over noradrenaline in response to carba- chol, but not $60 \mathrm{mmol} \mathrm{1}^{-1} \mathrm{~K}^{+}$, is consistent with the presence of both noradrenaline- and adrenaline-containing cells with the adrenaline-containing cells having a greater sensitivity to cholinergic stimulation than the noradrenaline-containing cells. Similar trends were observed in the American eel.

\subsection{Differences in storage levels}

Both the concentration of catecholamines within the chromaffin tissue of various species as well as the prevalence of one catecholamine over the other can differ to a large extent within, and between, different classes of fish (Table 1) [235]. This is evident from an early study [281] that reports storage levels of adrenaline and noradrenaline in various organs from a cyclostome ( $M$. glutinosa), an elasmobranch ( $S$. acanthias) and a teleost (G. callarius).

An early study on Myxine, [281] reported substantially greater levels of noradrenaline than adrenaline in the kidney-great veins, the atria of the systemic heart 
and in the entire portal heart whereas in the ventricle of the systemic heart, adrenaline was the primary catecholamine. A recent study, [220] reports equivalent levels of both catecholamines in the systemic heart of Myxine yet, in the posterior cardinal vein noradrenaline was dominant. In another cyclostome, Petromyzon marinus [175] the concentration of adrenaline was greater than noradrenaline in both the systemic atrium and ventricle. In the dipnoan (Protopterus aethiopicus), noradrenaline is predominant in the heart while adrenaline is the primary catecholamine stored in the intercostal arteries [4].

Within the axillary bodies/sympathetic chain ganglia in elasmobranchs, noradrenaline appears to be the predominant catecholamine. In the spiny dogfish, $S$. acanthias, several studies [2,281] observed greater quantities of noradrenaline than adrenaline in the sympathetic chain/axillary bodies $[2,281]$. Within the axillary bodies of another elasmobranch, Chimarea monstrosa, the concentration of noradrenaline was approximately 2.5 times that of adrenaline [232]. The concentration of stored catecholamines in elasmobranchs thus appears to be substantially larger than in other fish species. However, these enhanced storage levels do not appear to be manifested as larger levels of circulating catecholamines observed during stress. Indeed, during various stressful situations, levels of circulating catecholamines in teleosts appear, in general, to be greater than those in elasmobranchs $[43,42,267]$. Adrenaline is the predominant catecholamine within the cardinal veins in two species of ganoids L. platyrhincus [200] and Huso huso [20].

In teleost species there also exist various differences in the levels of stored catecholamines amongst species and even amongst the same species examined by different investigators. The extent to which these differences, within the same species, are due to differences in experimental approach is unknown. Unlike elasombranchs where noradrenaline is the predominant catecholamine and cyclostomes where the prevalence of one catecholamine over the other is tissue specific, in teleost fish adrenaline is the primary stored catecholamine in most species studied to date. In rainbow trout, O. mykiss, one study [188] observed approximately equivalent levels of noradrenaline and adrenaline in the head kidney. However, other investigators [239] observed greater levels of adrenaline than noradrenaline in regions of the main branch of the posterior cardinal vein and in regions of kidney tissue. It is evident from these studies that the anterior two thirds of the posterior cardinal vein is the primary storage site for catecholamines with little contribution from the kidney tissue itself. As with the rainbow trout, the primary storage site for catecholamines in the American eel (Anguilla rostrata) is also the anterior region of the posterior cardinal vein and adrenaline is predominant over noradrenaline.
Again, differences in absolute levels of these hormone are found between studies and the tissue regions studied $[115,239]$. The reason for the differences between these two studies is unknown but it is evident that the concentration of stored adrenaline is two to four times greater than stored noradrenaline.

In the common cod ( $G$. callarius), adrenaline is the exclusive catecholamine within the head kidney with virtually undetectable levels of noradrenaline [281]. In the Atlantic cod (G. morhua), [7] adrenaline is also found in greater quantities than noradrenaline in the cardinal veins. In C. carassius [197] and C. carpio [257] the levels of stored catecholamines are substantially reduced compared to the other teleost species reported.

It is evident that within fish species there is substantial variability in the absolute values of stored catecholamines and the ratio of adrenaline to noradrenaline as well as differences within the same species reported by various investigators. It would appear that in the cyclostomes and elasmobranchs, noradrenaline is the predominant catecholamine whilst in the teleosts (with the exception of the carp), adrenaline is predominant. It is possible that, in teleosts, the prevalence of adrenaline over noradrenaline represents an evolutionary alteration/up-regulation in the enzymatic processes required to synthesize adrenaline. It is plausible that in teleosts, compared with cyclostomes and elasmobranchs, (PNMT) has a greater activity/substrate affinity or is more resistant to degradation.

\subsection{Modulation of storage levels}

The acute adrenergic response in fish can be substantially modified by the prior history of the fish as well as environmental factors. Indeed, as mentioned above, a variety of factors (hormonal and neuronal) are capable of regulating and modulating the activity of the enzymes involved in biosynthesis. However, these hormonal and neuronal modulatory influences are generally 'expressed' only upon exposure of the animal (fish or otherwise) to various internal or external conditions which either stress the animal or necessitate an alteration in the capacity to express the adrenergic stress response. In fish, a variety of conditions such as anoxia, pollution, nutritive stress, physical stress and hormonal influences can all modify the levels of stored catecholamines in fish chromaffin tissue.

Recently, it was demonstrated that long-term exposure $(76-160 \mathrm{~h})$ of crucian carp, C. carassius L. to anoxic conditions produced a substantial decrease in stored noradrenaline levels within the head kidney [196]. Moreover, re-establishment of normoxic conditions resulted in a return to pre-anoxia storage levels after only 40 min suggesting an efficient synthesis pathway given the availability of molecular oxygen. Conversely, exposure of this same species to 17 days of 
anoxia [197] produced a $92 \%$ decrease in stored noradrenaline levels which, upon re-exposure to normoxia, did not recover to pre-anoxia levels. In both studies $[196,197]$, there were no effects of anoxia on stored adrenaline levels. It is possible [197] that the differences in the recovery of storage levels from anoxia in the two studies may reflect inactivation of $\mathrm{D} \beta \mathrm{H}$ given its requirement for molecular oxygen as a cofactor. It remains to be seen whether storage levels would recover if the animals were maintained under normoxic conditions for longer periods of time following the anoxic exposure. Presumably de novo synthesis of biosynthetic enzymes would permit the synthesis of catecholamines, given the necessary substrates, and recovery of storage levels.

Another environmental perturbation that can diminish levels of stored catecholamines in chromaffin tissue is exposure to various organic pollutants. Several industrial complexing agents, diethyldithiocarbamate (DOC) and amylxanthate (AX) form complexes with heavy metals, increasing their availability to fish and compromising the animals health $[31,275]$. Exposure of rainbow trout to DOC for a period of $24 \mathrm{~h}$ caused a decrease in both adrenaline and noradrenaline storage levels whereas exposure to $\mathrm{AX}$ for $24 \mathrm{~h}$ resulted in a decrease in stored noradrenaline, but not adrenaline [198]. It was hypothesized [198] that the decrease in storage levels, following these treatments, is due to an inhibition of $\mathrm{D} \beta \mathrm{H}$ arising as a result of these agents complexing $\mathrm{Cu}^{2+}$ ions which are essential for normal $\mathrm{D} \beta \mathrm{H}$ function.

In addition to environmental perturbations such as anoxia and pollution, the nutritional status of the animal may also influence the levels of stored catecholamines. Depriving rainbow trout of food for a period of 2 months produced a decrease in the total content of catecholamines ( $\mu \mathrm{g}$ of catecholamines) stored within the kidney and posterior cardinal vein, compared with normally fed fish [238]. The lower catecholamine content in these tissues is consistent with the diminished tissue weight of the kidney and PCV following food deprivation. Contrary to the decrease in total catecholamine content, the concentration of catecholamines ( $\mu$ g catecholamine $\mathrm{g}^{-1}$ tissue weight) within these tissues was unaffected by the starvation regimen. Tyrosine, the amino acid precursor of catecholamines, is obtained both from dietary intake and existing protein stores. The maintenance of catecholamine concentrations, during starving, suggests that existing stores were able to provide adequate tyrosine, and any other nutrients required, for catecholamine biosynthesis. However, if during the fasting period the fish encountered an acute stress which necessitated an elevation of plasma catecholamines, then nutrient deprivation may compromise the ability of the chromaffin cells to synthesize additional catecholamines and maintain storage levels.
A possible chronic or frequent stress that a fish may encounter is chasing by larger fish. In rainbow trout, an experimental protocol of twice daily chasing to exhaustion for a period of 5 days, markedly elevates plasma catecholamine levels [297]. Presumably, constant release of catecholamines during chasing would deplete, in part, the levels of catecholamines within the chromaffin cells. The sympathetic nervous stimulation of the chromaffin cells, in conjunction with adrenaline release and elevated plasma cortisol levels following chasing [71], would presumably stimulate the biosynthesis of catecholamines by increasing the activity of $\mathrm{TH}, \mathrm{D} \beta \mathrm{H}$ and PNMT (see above). Such a chasing protocol however, [238] did not alter the levels of catecholamines stored within the kidney and posterior cardinal vein suggesting that catecholamine biosynthesis is able to regulate and maintain the normal levels of catecholamines within the chromaffin cells. The ability of trout to maintain stored catecholamines at a 'normal' level, despite repeated release due to chasing, ensures that sufficient quantities are available to allow for an elevation of plasma catecholamines should another acute stress be encountered.

The aforementioned modulating effects on catecholamine storage levels discussed above have focused on conditions imposed by the environment, including manipulation by investigators (i.e. anoxia, pollution, food deprivation and chasing). However, internal hormonal factors are also capable of influencing the levels of stored catecholamines. The effects of corticosteroids, produced by steroidogenic interrenal cells (i.e. the adrenal cortex or its homologue), on catecholamine biosynthesis in mammalian species has received substantial attention over the past decade. In particular, corticosteroids, such as cortisol, can increase levels of stored adrenaline in the mammalian adrenal gland by increasing the activity of PNMT [29,84,129,300,301]. Corticosteroids, in mammalian species, can cause an increase in PNMT activity by influencing gene transcription, messenger RNA stability, translation, and enzyme activity and stability [303]. However, few studies have investigated possible interactions between corticosteroids and catecholamine biosynthesis in fish and it appears as if, unlike in mammals, cortisol does not increase in vitro PNMT activity in rainbow trout $[137,175]$.

Treatment of rainbow trout with an intraperitoneal implant of cortisol suspended in coconut oil results in a chronic elevation of plasma cortisol levels $[227,279]$ as cortisol is slowly released, from the implant, into the body fluid over a long period of time. Cortisol treatment for 1 day had no affect on the level of stored catecholamines in the kidney and posterior cardinal vein whereas following 3 and 7 days of treatment, levels of stored noradrenaline and adrenaline were elevated over control levels [241]. This increase in stored catecholamines was not accompanied by an increase in 
PNMT activity, measured in vitro, on either day [241]. Thus, it is likely that the effect of cortisol treatment on the enhanced level of catecholamine storage was occurring prior to the conversion of noradrenaline to adrenaline. Chronic cortisol treatment can increase the activity of $\mathrm{D} \beta \mathrm{H}$ in rainbow trout, suggesting that cortisol may function by decreasing the degradation of this enzyme [137]. Thus, whilst cortisol in higher vertebrates appears to enhance the activity of PNMT, in lower vertebrates, including fish, cortisol may exert effects on other enzymes of the Blaschko pathway.

\section{Situations eliciting catecholamine secretion}

Catecholamines are mobilized into the circulation of fish during a variety of stressful situations [235] which in general either require modulation of cardiorespiratory function or mobilization of energy reserves. The magnitude of the elevation in plasma catecholamine levels can vary depending upon the type of stress imposed, the severity of the stress and the species. Various levels of plasma catecholamines in five teleost species (O. mykiss, Salmo fario, G. morhua, C. carpio and Platichthys stellatus) in response to various stressors (external hypoxia, hypercapnia, exhaustive and violent exercise, air exposure, acid infusion or anaemia) are reviewed in reference [267]. Additionally, anaesthesia during experimental manipulation also produces a transient elevation of plasma catecholamine levels [126]. It is evident from the studies compiled in the aforementioned review that there are marked differences in the levels of plasma catecholamines observed in different species in response to different types of stress. The dominance of either adrenaline or noradrenaline in the circulation during a stressful period is not only dependent upon storage levels $[25,28,41,42,66,220]$ but also on the rate of metabolic degradation $[56,191,192]$, accumulation of catecholamines into tissues $[40,190,191,271$, 272] and the 'ability' of chromaffin cells to secrete catecholamines [239].

In mammals, plasma catecholamines can originate not only from the adrenal chromaffin cells but also from sympathetic neurons. However, in fish (Atlantic cod, [219] overflow from peripheral adrenergic nerve terminals does not significantly contribute to the elevation of plasma catecholamine levels.

\subsection{Catecholamine release during hypoxia}

One of the more prevalent environmental/experimental conditions eliciting an elevation of plasma catecholamine levels is external hypoxia $[14,28,36,41,89,92$, $138,140,177,219,225,226,231,235,239,246,268]$. Additionally, plasma catecholamine levels are also elevated during air exposure [94,203]. The release of cate- cholamines into the circulation during hypoxia can be influenced by the severity of the hypoxic exposure. In the Atlantic cod, a gradual decrease in water $P_{\mathrm{O}_{2}}$ caused an elevation of plasma adrenaline levels whereas a rapid decrease in water $P_{\mathrm{O}_{2}}$ caused a simultaneous elevation of both adrenaline and noradrenaline [219]. Also in the cod, during the imposition of a hypoxic stress, noradrenaline appears in the blood prior to adrenaline [91].

Depending upon the severity of environmental hypoxia, either the partial pressure of oxygen $\left(\mathrm{Pa}_{\mathrm{O}_{2}}\right)$ in the arterial blood or both the $\mathrm{Pa}_{\mathrm{O}_{2}}$ and the arterial oxygen content may decrease. Given the sigmoidal nature of the oxygen equilibrium curve and the obligate relationship between $P_{\mathrm{O}_{2}}$ and oxygen content [287,288], it has proven difficult to distinguish between the effects of these two variables on promoting catecholamine release during hypoxia. A linkage between blood oxygen content/haemoglobin- $\mathrm{O}_{2}$ saturation and plasma catecholamine levels has been suggested by several studies. First, anemic fish release catecholamines into the circulation [125,222] even under hyperoxic conditions [222]. In anemic fish, haemoglobin- $\mathrm{O}_{2}$ saturation is not lowered, suggesting a specific role in the lowering of blood oxygen content in causing release. Second, catecholamine release during hypercapnic acidosis in trout is a result of the associated hypoxemia (owing to the Root effect) rather than the acidosis itself ([222]; see below). Third, one study [89] reported that the $\mathrm{Pa}_{\mathrm{O}_{2}}$ threshold for release was substantially lowered after repeated episodes of acute hypoxia suggesting that haemoglobin- $\mathrm{O}_{2}$ affinity was raised after the initial episode of hypoxia (a result, at least in part, of catecholamine release [193] and thus led to the lowering of the $P \mathrm{a}_{\mathrm{O}}$ threshold).

In order to elucidate the proximate stimulus (a depression of $\mathrm{Pa}_{\mathrm{O}_{2}}$ or arterial oxygen content) for the release of catecholamines during hypoxia, rainbow trout and American eels were exposed to varying degrees of acute $(30 \mathrm{~min})$ hypoxia $\left(90-35\right.$ torr water $\left.P_{\mathrm{O}_{2}}\right)$ [225]. Based on in vivo oxygen equilibrium curves, the $\mathrm{P}_{50}$ values (the $P \mathrm{a}_{\mathrm{O}_{2}}$ at which the oxygen content of the blood is $50 \%$ of its maximal value) in the rainbow trout, and American eel were 23 and 11 torr, respectively. Thus the affinity of the oxygen-haemoglobin binding reaction is substantially enhanced in the eel over the trout. During hypoxic exposure, defined $\mathrm{Pa}_{\mathrm{O}_{2}}$ and oxygen content thresholds for the release of catecholamines were determined. While the $\mathrm{Pa}_{\mathrm{O}_{2}}$ thresholds differed in the two species, in accordance with the different haemoglobin- $\mathrm{O}_{2}$ binding affinities, the oxygen content thresholds were almost identical, corresponding to approximately $45-60 \%$ haemoglobin- $\mathrm{O}_{2}$ saturation. The similar oxygen content thresholds for release imply that a depression of blood oxygen content, rather than $\mathrm{Pa}_{\mathrm{O}_{2}}$, is the proximate stimulus for catecholamine release during hypoxia. 
However, the aforementioned study [225] could not exclude the possibility that a depression of $\mathrm{Pa}_{\mathrm{O}_{2}}$ is the proximate stimulus for release with trout and eel possessing intrinsically different $\mathrm{Pa}_{\mathrm{O}_{2}}$ thresholds. In order to differentiate between these two possibilities, rainbow trout were acclimated [226] to either 5 or $15^{\circ} \mathrm{C}$ for a period of 2 months in order to manipulate the intrinsic properties of haemoglobin-oxygen binding and to assess the impact on the dynamics of catecholamine release during hypoxia. Temperature acclimation led to an enhanced haemoglobin- $\mathrm{O}_{2}$ binding affinity at the lower temperature with $P_{50}$ values of 14 and 27 torr in the 5 and $15^{\circ} \mathrm{C}$ fish, respectively. During exposure to acute hypoxia, the $\mathrm{Pa}_{\mathrm{O}_{2}}$ threshold at which catecholamines were released into the circulation was lower in the $5^{\circ} \mathrm{C}$ fish (24 torr) than in the $15^{\circ} \mathrm{C}$ fish (35 torr). However, in agreement with reference [225], release thresholds calculated on the basis of arterial blood oxygen content were similar at both temperatures. Thus, the results of these aforementioned studies $[89,125,222,225,226]$ provide compelling evidence that a depression of blood oxygen content is the modality which triggers the mobilization of catecholamines into the circulation rather than a depression of $\mathrm{PaO}_{2}$.

\subsection{Catecholamine release during hypercapnia/acidosis}

One of the primary roles of circulating catecholamines in fish is to maintain or elevate blood oxygen levels under conditions that depress blood oxygen content. The hydration of $\mathrm{CO}_{2}$ into protons and bicarbonate ions $\left(\mathrm{CO}_{2}+\mathrm{H}_{2} \mathrm{O} \leftrightarrow \mathrm{HCO}_{3}^{-}+\mathrm{H}^{+}\right)$often results in a respiratory acidosis accompanying hypercapnic exposure (an increase in $\mathrm{CO}_{2}$ within the water). Given the detrimental effects of $\mathrm{H}^{+}$and $\mathrm{CO}_{2}$ on haemoglobin-oxygen binding, it is not surprising that plasma catecholamine levels are often elevated during exposure to environmental hypercapnia $[123,221,222$, 224]. Additionally, the introduction of acid into the water [304] and conditions of metabolic acidosis [14,35] are also associated with elevated plasma catecholamine concentrations.

Various studies have reported a correlation/relationship between blood $\mathrm{pH}$ and plasma catecholamine levels $[35,225,263]$. However, given the relationship between blood oxygen content and acid-base status in teleost fish, particularly rainbow trout $[221,231,266,267]$ and the promotion of hypoxemia during acidosis via Root and Bohr effects, it is difficult to determine if a decrease in blood $\mathrm{pH}$ is sufficient, in the absence of hypoxemia, to cause the secretion of catecholamines. However, several studies [14,222] demonstrated that acidosis does not promote catecholamine secretion in the absence of blood hypoxemia suggesting no direct role for acidosis in catecholamine secretion.
An additional complicating factor in assessing the role of acidic conditions in promoting catecholamine release is the difficulty in distinguishing the cause of release from the consequences of catecholamine release. In teleosts, circulating catecholamines can activate a $\mathrm{Na}^{+} / \mathrm{H}^{+}$antiporter on the red blood cell that extrudes protons from the red cell in exchange for plasma sodium ions causing acidification of the plasma and alkalization of the erythrocyte [184,194,195,267]. The subsequent increase in red blood cell intracellular $\mathrm{pH}$ can promote an increase in blood oxygen content through Bohr and Root effects [85,120,193,195,231, 247]. Given red blood cell $\mathrm{Na}^{+} / \mathrm{H}^{+}$exchange, an elevation of plasma catecholamines is often accompanied by a decrease in plasma $\mathrm{pH}$ and therefore it is difficult to separate the cause of catecholamine secretion from the effects of release. It would appear that during exposure to hypercapnic conditions, the mobilization of catecholamines into the circulation is a result of a lowering of blood oxygen content due to Bohr and Root effects rather than a direct effect of $\mathrm{pH}$ per se.

\subsection{Catecholamine release during exercise}

Fish exposed to a variety of regimens of exhaustive or violent exercise release catecholamines into the circulation in varying quantities $[18,43,44,101,169,178,188$, $208,210,228,234,245,263,274,292,294-297]$. During exercise, catecholamines will exert energy mobilizing effects and thus increase the blood borne energy supplies via activation of liver glycogenolysis and gluconeogenesis along with an inhibition of glycolysis [180$182,214,215]$. Additionally, the catecholamine-induced enhancement of gas transfer across the gills, and oxygen transport in the blood, will prove beneficial during exercise.

Contrary to the catecholamine-mobilising effect of exercise in many fish species, this form of perturbation does not cause an elevation of circulating catecholamine levels in notothenioids (i.e. two nototheniids, $N$. coriiceps, $N$. rossii and an icefish, C. aceratus) [77]. Additionally, handling stress also fails to initiate the mobilisation of catecholamines in these fish $[67,76]$. The authors of these studies [67,77] suggest that the low levels of circulating catecholamines may reflect a greater propensity of the autonomic cholinergic system, rather than blood-borne catecholamines, to regulate certain aspects of the stress response in these species.

\subsection{The effects of softwater on catecholamine release}

Diminished resting levels of circulating catecholamines were observed in rainbow trout following three weeks of acclimation to ion-poor water (softwater [229]). Exposure of freshwater rainbow trout 
$[16,110,111,155-157,223,230,256]$ and other teleosts [164] to softwater induces a proliferation of gill chloride cells which thicken and cover the respiratory (pavement) cells. The resulting thickening of the blood to water diffusion distance can subsequently impair gas transfer leading to a decreased arterial $\mathrm{Pa}_{\mathrm{O}_{2}}$ and an increased $\mathrm{Pa}_{\mathrm{CO}_{2}}$ [110]. Given the beneficial effects of catecholamines on both gas transport across the gills and transfer within the blood $[231,235,267]$, it is likely that circulating catecholamine levels are elevated during the early stages of softwater acclimation in order to compensate for the detrimental effects of a thickening in the blood to water diffusion distance. Given the chronic imposition of this stress (softwater exposure), it is likely that a continual release of catecholamines may occur which ultimately results in a depletion of storage levels and/or desensitization of the release process. Both of these factors could lead to an attenuation of plasma catecholamine levels following the 3 weeks of acclimation to softwater conditions.

The dynamics of catecholamine release during exposure to acute hypoxia can also be modified by softwater acclimation. Upon exposure to graded levels of environmental hypoxia, softwater-acclimated rainbow trout mobilize catecholamines into their circulation at a significantly higher $P \mathrm{w}_{\mathrm{O}_{2}}$ than trout maintained under normal ionic conditions [229]. Under softwater and control conditions, defined arterial $P_{\mathrm{O}_{2}}$ thresholds for catecholamine release were 24 and 40 torr in control and softwater-acclimated trout, respectively. The elevated release threshold in the softwater acclimated fish arises from the downward displacement of the $\mathrm{Pa}_{\mathrm{O}_{2}}-P_{\mathrm{w}_{\mathrm{O}_{2}}}$ relationship in combination with a left shifted oxygen equilibrium curve. The elevated release threshold in softwater acclimated fish affords the fish with the physiological benefits of an elevation of plasma catecholamine levels [231] at a time when gas transfer/transport may be compromised by the increased diffusion distance.

In addition to reduced resting plasma catecholamine levels and an increased $\mathrm{Pa}_{\mathrm{O}_{2}}$ threshold for the release of catecholamines during hypoxia, the absolute magnitude of plasma catecholamine levels, during severe hypoxia $\left(P_{\mathrm{w}_{\mathrm{O}_{2}}}=30-35\right.$ torr), was diminished in softwater acclimated rainbow trout [229]. As mentioned above, either a depletion of storage levels or desensitization of the release process may lead to diminished plasma levels during stress, including hypoxia (see also modulation of cholinergicinduced catecholamine release below). Alternately, depleted plasma levels may also reflect changes in the rates of catecholamines synthesis and/or degradation.

\section{Mechanisms and modulation of catecholamine release}

\subsection{Cholinergic control of catecholamine release}

\subsubsection{Chromaffin cell cholinoceptor pharmacology}

Undoubtedly the primary mechanism leading to the secretion of catecholamines from the chromaffin cells in teleost and elasmobranch fish is stimulation of these cells by the sympathetic nervous system $[2,116,199,201$, 202,219]. More precisely, chromaffin cells are innervated by pre-ganglionic sympathetic fibers which release the neurotransmitter acetylcholine (Ach) (and possibly others; [112,237,284]) onto the chromaffin cells where it interacts, with cholinergic receptors (cholinoceptors), to initiate the secretion of catecholamines via exocytosis ([37]; Fig. 2). In the majority of vertebrate species studied to date, including fish, it appears as if the nicotinic receptor is the predominant cholinoceptor present on chromaffin cells (see below).

Stimulation of nicotinic cholinoceptors ultimately leads to the opening of calcium channels and the entry of $\mathrm{Ca}^{2+}$ ions into the cell from the extracellular fluid ([37-39,99,270]; see Fig. 1). The ensuing elevation of intracellular calcium levels triggers a series of events, including rearrangement of the cytoskeleton, which allows the catecholamine-containing secretory granules to move towards and fuse with the plasma membrane thereby releasing their contents into the extracellular space via exocytosis (Fig. 2). The process of exocytosis involves multiple stages and substances which mediate the movement of secretory vesicles to the plasma membrane, the docking of the vesicles to the plasma membrane, fusion of granule and plasma membranes to allow release of the contents and the ultimate recovery of the granule membrane via endocytosis [37].

The nicotinic nature of the cholinergic-induced catecholamine secretory response from fish chromaffin cells has been demonstrated in several studies. In the Atlantic cod, G. morhua, either electrical stimulation of the sympathetic nerves which innervate the head kidney, or application of acetylcholine to the head kidney, caused catecholamine release from in situ perfused preparations [2,203,219,282]. The secretion of catecholamines in response to either of these stimuli can be prevented by treatment of the preparation with the ganglionic blocker, hexamethonium, that inhibits nicotinic cholinoceptors.

Although stimulation of the nicotinic cholinoceptor, and the ensuing signal transduction events following receptor activation, is the primary mediator of cholinergic-induced catecholamine secretion, the involvement of muscarinic cholinoceptors in this process is also common across various vertebrate phyla (Fig. 2). Indeed in non-fish vertebrate species, stimulation of chromaffin cells with muscarinic agonists can enhance nicotinic- 


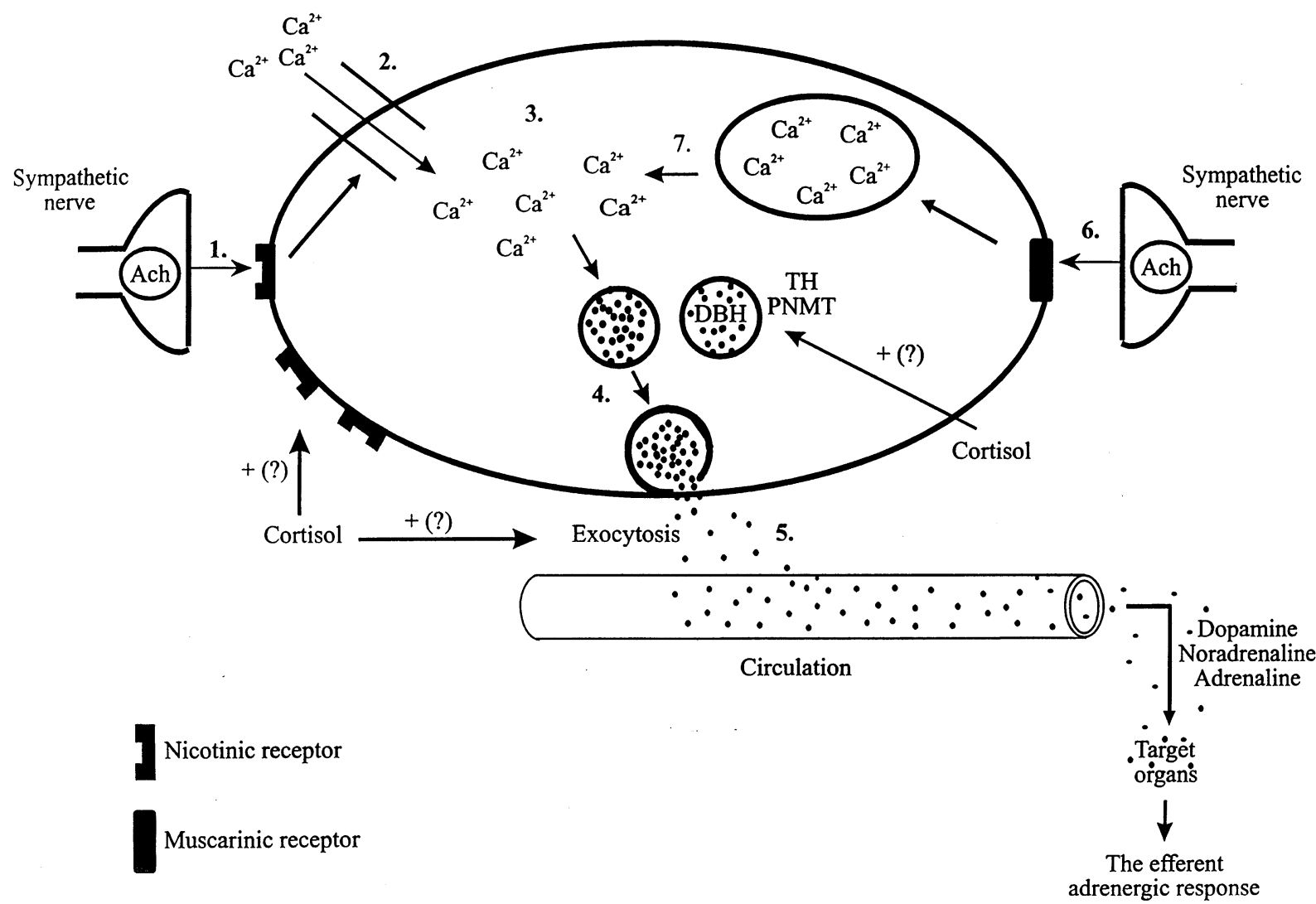

Fig. 2. A schematic diagram of the cholinergic pathway of catecholamine secretion from fish chromaffin cells. Acetylcholine released from sympathetic nerve fibers will stimulate the chromaffin cells by interacting with nicotinic [1] or possibly muscarinic [6] cholinoceptors. Stimulation of the nicotinic receptor ultimately leads to the opening of a calcium channel and the entry into the cell of $\mathrm{Ca}^{2+}$ ions [2]. Muscarinic receptor activation leads to the release of $\mathrm{Ca}^{2}+$ from intracellular stores [7] such as the endoplasmic reticulum. The involvement of these two receptor types in the cholinergic control of catecholamine secretion can vary amongst fish species (see text). The ensuing rise of intracellular $\mathrm{Ca}^{2+}$ levels [3] can lead to a series of intracellular events, including rearrangement of the cytoskeleton [37], facilitating the movement of secretory granules to the plasma membrane [4] where they release their contents via exocytosis [5]. The catecholamine hormones can then diffuse into the blood where they circulate until reaching the appropriate target organs and initiate the efferent limb of the adrenergic response. The corticosteroid cortisol can enhance catecholamine storage levels possibly by up-regulating enzymes within the biosynthetic pathway (see text). Also, cortisol may influence the number/affinity of cholinoceptors on the chromaffin cell membrane, sensitising the release process to sympathetic nerve stimulation.

evoked release [90], inhibit nicotinic-evoked release $[49,70,262]$, stimulate secretion in the absence of nicotinic agonists [21,143,159,269] or exert no effect on catecholamine secretion [166]. Thus, amongst non-fish vertebrate species so far studied, cholinoceptor-induced secretion of catecholamines from chromaffin cells is certainly not confined to a series of nicotinic receptorevoked events.

As with other vertebrate species, it would appear as if the presence of muscarinic receptors on chromaffin cells in fish might also exhibit substantial variability. In rainbow trout, $O$. mykiss, the release of catecholamines in situ can be stimulated by treatment with the mixed nicotinic/muscarinic agonist carbachol (carbamylcholine; [93,238-241]) an analogue of the endogenous neurotransmitter acetylcholine which exhibits enhanced resistance, compared with acetylcholine, to degradation by endogenous cholinesterases. Treatment of the rainbow trout perfusion preparation with hexamethonium inhibited the release of noradrenaline and attenuated the release of adrenaline in response to carbachol [93], suggesting a role for the muscarinic receptor in the cholinergic release of catecholamines in this species. The incomplete inhibition of carbachol-evoked adrenaline release with hexamethonium implies a role for muscarinic receptors in the secretion of adrenaline, but not noradrenaline, suggesting a possible differential distribution of muscarinic cholinoceptors on the different types of chromaffin cells (adrenaline- and noradrenaline-containing cells, see above).

In another teleost species, the American eel ( $A$. rostrata), the muscarinic cholinoceptor does not appear to mediate the secretion of catecholamines from chromaffin cells. Administration of carbachol to an in situ perfused posterior cardinal vein preparation in this species also stimulated both adrenaline and noradrenaline secretion which was abolished with hexamethonium (Fig. 1G) yet unaffected by the classical 
antimuscarinic, atropine [240]. Additionally, catecholamine secretion in this species was also evoked, in situ, by application of the nicotinic receptor agonist 1,1-dimethyl-4-phenylpiperazinium iodide (DMPP) but not by the muscarinic agonist, pilocarpine. Secretion in response to DMPP was, like carbachol-evoked release, abolished by pre-treatment with hexamethonium. Given these results $[93,240]$ it appears as if a muscarinic receptor is involved in catecholamine, particularly adrenaline, secretion in rainbow trout, but not in American eel. Therefore, as with non-fish vertebrates, the type of cholinoceptor mediating the cholinergic secretion of catecholamines in fish may also exhibit species to species variability.

Although stimulation of chromaffin cells by the sympathetic nervous system is undoubtedly the primary stimulus evoking the secretion of catecholamines from chromaffin cells in most fish species, it is clearly not the exclusive pathway of release. The presence of other mechanisms leading to catecholamine secretion in teleost fish is evident from experiments in which the sympathetic fibers innervating the chromaffin cells are sectioned in order to eliminate sympathetic stimulation of these cells. Bilateral sectioning of spinal nerves 1-4 innervating the head kidney in the Atlantic cod attenuated but did not abolish the elevation of plasma catecholamines during air exposure [283], after exhaustive exercise [44] or during environmental hypoxia [219]. It is apparent therefore, that mechanisms other than cholinergic pathways are involved in the process of catecholamine secretion in this species. Non-cholinergic control of release is discussed in the final section of this review.

\subsubsection{Differential secretion of catecholamines in response to cholinergic stimulation}

In addition to differences in the nature of cholinoceptor pharmacology on the chromaffin cells of rainbow trout and American eels, there are also apparent differences in the nature of the secretory response in these two species with respect to the quantity of catecholamines released. Exposure of rainbow trout and American eels to severe environmental hypoxia $\left(P \mathrm{w}_{\mathrm{O}_{2}}=30-35\right.$ torr; [225,226]) results in a substantial elevation of plasma catecholamines in the rainbow trout $\left(100-300 \mathrm{nmol} 1^{-1}\right)$ yet very moderate increases in the eel $\left(2-5 \mathrm{nmol} 1^{-1}\right)$. These widely different plasma catecholamine levels cannot be ascribed to the differences in oxygen-haemoglobin binding and release thresholds (see above). Additionally the 4-fold difference in levels of stored catecholamines in these two species (see above) cannot account for the approximately 100 -fold difference in the plasma values observed during severe hypoxia.

In an attempt to elucidate the mechanism(s) underlying these differences in plasma catecholamine levels, the 'ability' (i.e. efficacy/efficiency) of the chromaffin cells in these two species to release catecholamines, in situ, in response to stimulation with carbachol was examined [239]. In response to this stimulus, rainbow trout chromaffin cells secreted substantially greater quantities of catecholamines than eel chromaffin cells. The affinity of the secretory process, for carbachol, was equivalent in both species suggesting that chromaffin cells in rainbow trout possess greater numbers of cholinergic receptors than those in the eel or that one or more post-receptor events is amplified in the trout compared to the eel. Also, these differences may be explained if there are a greater number of chromaffin cells in the trout, however, to date this has not been demonstrated. Additionally, it is possible that eel chromaffin cells are less densely innervated by cholinergic fibers than those in the trout, although this would account for the in vivo but not the in situ differences. This differential ability to respond to cholinergic stimulation may explain the interspecific differences observed in plasma catecholamine levels during exposure to environmental hypoxia.

Unlike teleost fish, the chromaffin cells in cyclostomes/agnathans (i.e. hagfish and lampreys) lack any form of extrinsic innervation $[15,127,128]$. As such, the primary mechanism of catecholamine secretion seen in other vertebrates (i.e. neuronal stimulation by the sympathetic nervous system) is lacking. Interestingly however, the cholinergic agonist carbachol is capable of eliciting catecholamine release, in situ, in the Atlantic hagfish, M. glutinosa [220]. However, it is unlikely that stimulation of the chromaffin cells by endogenous acetylcholine is a physiologically relevant stimulation given that this neurotransmitter does not circulate in the blood. It is possible that the presence of cholinergic receptors on the chromaffin cells in this species represents a fundamental property of these cells reflecting their embryological origin (modified post-ganglionic cells derived from neural crest) and is independent of extrinsic innervation. Alternately, a population of chromaffin cells in this species (i.e. those in the great veins) might be innervated, and therefore possess cholinoceptors, while others (i.e. in the hearts, which were the focus of earlier morphological studies) are not [220]. Potential physiological mechanisms causing the in vivo mobilization of catecholamines in this species are discussed in the following section (non-cholinergic control).

\subsubsection{Modulation of cholinergic control of catecholamine release}

Just as storage levels of catecholamines can be modulated by factors such as anoxia, pollution, nutritive stress, physical stress and hormones, the process of cholinergic-induced catecholamine secretion can also be influenced by the prior history of the animal including 
the aforementioned conditions. Stresses such as physical disturbance (e.g. handling or chasing) $[23,188,245$, $280]$ and starvation/fasting [23,154,158,168,259,261,280] are encountered frequently in aquaculture and studies on fish physiology and metabolism. Similar stresses are also undoubtedly encountered in the natural environment.

Chasing rainbow trout to exhaustion once a day for either 1,3 or 7 days caused an immediate increase in plasma catecholamine levels that remain elevated for up to $30 \mathrm{~min}$ post-exhaustion [228]. However, on the 3rd and 7 th days of chasing, plasma catecholamine levels immediately post-chasing were significantly depressed compared with the post-chasing levels seen after only a single day of chasing. Given that a similar chasing protocol did not result in a depletion of catecholamine stores in this species [238], the depression of plasma levels on the 7 th day suggests an inhibition/desensitization of catecholamine release following repeated stress. This attenuation of release is consistent with the desensitization of carbachol-evoked catecholamine release, in situ, following 5 days of twice daily chasing to exhaustion [238]. Given that the sensitivity of release, in situ, was diminished rather than a decrease in the maximal quantity released, it is likely that the attenuation of in situ release resulted from a decrease in the affinity of cholinoceptors for carbachol rather than a reduction in receptor numbers. The reduction in plasma catecholamine levels following repeated stress, in vivo, likely functions to prevent an over expression of the efferent adrenergic stress response in accordance with general theories regarding receptor desensitization/ down-regulation [57,102,118].

While physical stress (chasing) appears to desensitize catecholamine release both in vivo and in situ, nutritive stress (fasting for 2 months) attenuates the levels of stored catecholamines (see above) but does impair the ability of the chromaffin cells to secrete catecholamines, in situ, in response to carbachol [238]. During longterm food deprivation, fish become hypometabolic [183] and therefore it is conceivable that under such circumstances fish would desensitize the process of catecholamine release in order to minimize any catecholamine-induced glycogenolysis. However, a 2month regimen of fasting did not produce such desensitization and indeed perhaps a more appropriate response would be to down-regulate the efferent adrenergic response on hepatocytes and muscles rather than attenuating the mobilization of catecholamines. In this manner, during an acute stress, the beneficial effects of catecholamines on gas transfer/transport can be maintained while avoiding undesirable metabolic effects.

The secretion of catecholamines into the circulation is generally considered to be a component of the acute stress response. However, the overall stress response in vertebrates also consists of a chronic component that involves the release, into the circulation, of corticosteroids $[71,101,176,233,280]$. Cortisol, the major corticosteroid produced by the steroidogenic interrenal cells in fish (which like the chromaffin cells are located within the head kidney in teleost fish, [189]), is released into the circulation upon stimulation of the interrenal cells by adrenocorticotropic hormone (ACTH) released from the pituitary gland [17]. In rainbow trout, 7 days of chronic cortisol treatment enhanced the sensitivity of in situ catecholamine release in response to stimulation with carbachol without altering maximal levels of release [241]. It is possible that the enhanced sensitivity of the release process following cortisol treatment results from a cortisol-mediated increase in the affinity of cholinoceptors for carbachol. Alternately, cortisol may induce the de novo synthesis of cholinoceptors which may possess a greater affinity for carbachol than receptors already present on the chromaffin cell membrane. Additionally, any post-receptor modifications within the signal transduction pathway could account for the enhanced ability to release catecholamines. In addition to enhancing cholinergic-induced release of catecholamines, cortisol treatment also increased in situ basal adrenaline, but not noradrenaline, secretion, an observation which may reflect the enhanced levels of stored catecholamines following cortisol treatment (see above; Fig. 2).

Clearly cholinergic control of catecholamine release is not a static process but is subject to modification and modulation by a variety of factors, intrinsic and extrinsic. Although the cholinergic pathway of release is the primary mechanism inducing catecholamine release, the presence of non-cholinergic mechanisms creates the potential for a dynamic and diverse secretory response from fish chromaffin cells.

\subsection{Non-cholinergic control of catecholamine release}

Recent advances in the assessment of the role of catecholamines in physiological control have described multiple patterns in the activation of catecholamine release that vary with the nature and severity of stress [149]. In addition to cholinergic innervation, there is considerable evidence that a large number of noncholinergic neurotransmitters and hormones can also evoke or modulate adrenaline and noradrenaline release in vertebrates [37,167]. Overall, the control of chromaffin cell activity in mammals involves neural signals from cholinergic and peptidergic nerve fibers, and humoral signals of circulatory, paracrine, or autocrine origin. In fish, a number of recent studies suggest that the control of catecholamine release may also involve all of the above mechanisms and that significant species differences may also exist ([25-27,83,93,142,237,241]; Fig. 3). In agnathans (hagfish and lamprey) however, the chromaffin cells are non-innervated $([25,66])$ and 


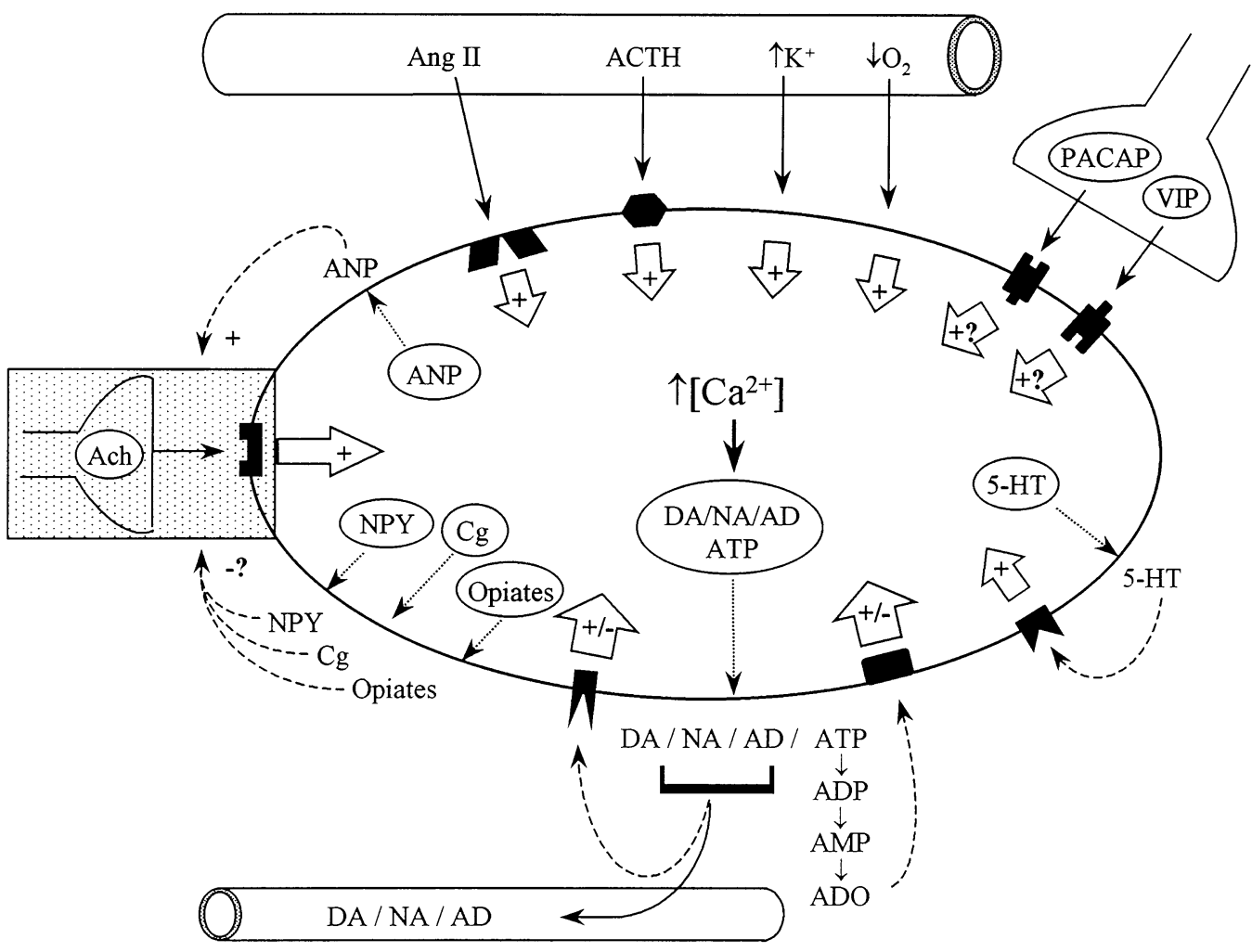

Fig. 3. Schematic diagram of the potential non-cholinergic mediators of catecholamine secretion in a generic fish chromaffin cell. Circulating angiotensin (II Ang II) and adrenocorticotropic hormone (ACTH) can increase (+) catecholamine secretion by stimulating their respective receptors on the surface of chromaffin cells. Similarly, an increase in $\mathrm{K}^{+}$or a decrease in oxygen can directly increase catecholamine secretion. The neurotransmitters pituitary adenylyl cyclase-activating polypeptide (PACAP) and vasoactive intestinal polypeptide (VIP) have been identified in chromaffin cells associated-nerve fibers in several fish species, and based on their effects on catecholamine secretion in mammals [54,112], these neurotransmitters may have stimulatory (+?) effects on catecholamine secretion in fish chromaffin cells. The secretion of serotonin (5-HT) by chromaffin cells, or other cell types in the head kidney, may lead to an increase in catecholamine secretion. Adenosine (ADO), presumably the product of ATP breakdown following exocytosis of catecholamines, can either increase or decrease ( + /-) catecholamine secretion. In addition to being released into the circulation, dopamine (DA), noradrenaline (NA), and adrenaline (AD), may either increase or decrease catecholamine secretion. There is immunohistochemical evidence for the presence of opiates, chromogranins $(\mathrm{Cg})$, and neuropeptide Y (NPY), in the chromaffin cells of some fish species. Based on their effects on catecholamine secretion in mammals [50], the above peptides may decrease (-?) the secretion of catecholamines elicited by cholinergic stimulation. Atrial natriuretic peptide (ANP) released by chromaffin cells may increase the acetylcholinestimulated (Ach) catecholamine secretion. Although the secondary messenger signals activated by these various secretagogues are not known, their effects on catecholamine secretion are most likely mediated by changes in the intracellular $\mathrm{Ca}^{2+}$ concentration ([Ca $\left.{ }^{2+}\right]$ ) [99]. Solid arrows represent endocrine or neuronal pathways, dashed arrows represent paracrine or autocrine pathways, and dotted arrows represent exocytosis of secretory granules.

thus the control of catecholamine release may be entirely via non-cholinergic mechanisms. Although several potential non-cholinergic secretagogues of catecholamines have been identified in fish, their relative contribution to the control of catecholamine release in vivo, and the physiological conditions under which they act have yet to be characterized.

\subsubsection{Non-humoral agents}

4.2.1.1. Potassium. Although perfusion of the chromaffin tissue with supraphysiological doses of $\mathrm{K}^{+}$results in a non-specific depolarization of the chromaffin cell and a marked release of catecholamines in all vertebrate species examined [37,220,239], the role of physiological concentrations of $\mathrm{K}^{+}$in the control of catecholamine release appears to be species specific. Whereas a moderate increase in perfusion saline $\left[\mathrm{K}^{+}\right]$ in an in situ preparation of $M$. glutinosa does not affect catecholamine release [220], injections of physiological doses of potassium ions does cause a dose-related increase in the concentration of circulating catecholamines in the dogfish shark, S. acanthias [206]. In view of the latter results, it was suggested [208] that the increase in plasma $\mathrm{K}^{+}$observed during and after exercise in $S$. acanthias may be, at least in part, responsible for the release of catecholamines and maintenance of plasma catecholamine levels in the post-exercise period. Furthermore, the stimulatory effects of $\mathrm{K}^{+}$in the dogfish are not blocked by pre-treatment with the cholinergic receptor antagonist hexamethonium $[209,210]$, suggesting that the effects of $\mathrm{K}^{+}$on cate- 
cholamine release are not mediated through the nicotinic receptor.

4.2.1.2. Oxygen. As mentioned above, a lowering of blood oxygen content may be one of the principle factors initiating the release of catecholamines from the chromaffin tissue in teleosts. Therefore, it is significant to note that both neuronal and non-neuronal mechanisms may be involved in mediating the control of catecholamine release during hypoxia in these fish. In the Atlantic cod (G. morhua), while sectioning the spinal nerves supplying the head kidney prevented a hypoxia-induced $\left(P_{\mathrm{w}_{\mathrm{O}_{2}}}=40\right.$ torr $)$ increase in plasma noradrenaline, it had no effect on the increase in plasma adrenaline [219]. Moreover, hypoxic blood $\left(\mathrm{Pa}_{\mathrm{O}_{2}}=23\right.$ torr $)$ directly stimulated adrenaline secretion in an in situ head kidney perfusion preparation of $G$. morhua [219].

Studies using cultured bovine chromaffin cells (BCC) have also shown that basal catecholamine release is elevated by anoxic incubation conditions [124]. However, while catecholamine release evoked by supraphysiological doses of $\mathrm{K}^{+}$in BCC may be enhanced after 10 min of anoxic incubation [124], several studies have also shown that hypoxia inhibits high- $\mathrm{K}^{+}$induced catecholamine release $[124,161,162]$. Moreover, anoxic incubation of $\mathrm{BCC}$ inhibits catecholamine release elicited by nicotine [161] and decreases the affinity of the nicotinic cholinoceptors [163].

4.2.1.3. Acidosis. While hypoxemia appears to be an essential requirement for catecholamine release following exposure to hypercapnic and/or acidotic conditions in vivo, the effect of regional acidosis on catecholamine release from the chromaffin tissue of the head kidney has yet to be directly assessed in teleosts. In agnathans, despite the observation that prolonged and severe hypoxic exposure can result in both blood acidosis and catecholamine release $[27,28,220]$, lowering the $\mathrm{pH}$ (from 8.1 to 7.0 ) of the saline perfusing the principle chromaffin tissue of $M$. glutinosa did not elicit catecholamine secretion [220]. Additionally, although exposure of cannulated Petromyzon marinus to $\mathrm{CO}_{2}$ is associated with a significant increase in plasma catecholamines [66], it remains to be seen whether this is due to a direct effect of blood acidosis on the chromaffin tissue.

In mammals, the influence of $\mathrm{pH}$ on the control of catecholamine release from the adrenal medulla is controversial. In BCC for example, while noradrenaline secretion evoked by carbachol was enhanced after a decrease in $\mathrm{pH}_{\mathrm{i}}(7.2-6.8$ [139]), acidosis of the incubation buffer $(\mathrm{pH} 7.4-6.0)$ was also shown to reduce nicotine-induced noradrenaline release and the corresponding intracellular $\mathrm{Ca}^{2+}$ transients [148]. In addition, perfusion of isolated rat adrenal glands with an acidified buffer solution elicited an increase in intracellular $\mathrm{Ca}^{2+}$ transients (detectable at $\mathrm{pH} 7.0$ and increased until $\mathrm{pH} \sim 6.4$ ) while stimulating adrenaline, but not noradrenaline, secretion [98].

\subsubsection{Humoral agents}

4.2.2.1. Serotonin. In addition to catecholamines, the head kidney region of several fish species also stores the biogenic amine serotonin (5-hydroxytryptamine; [237]). While these serotonin stores have been immunohistochemically localized in chromaffin cells of both the Atlantic cod and European eel, within the head kidney of the rainbow trout, serotonin appears to be stored in a cell-type other than the chromaffin cell [237]. Tissue extracts from the rainbow trout posterior cardinal vein contain large quantities of serotonin (44.6 $\mu \mathrm{g} \mathrm{g}^{-1}$; [93]), a storage level equivalent to that of adrenaline and noradrenaline [239]. Positive immunohistochemical labeling for antisera raised against serotonin was also observed in both the systemic and portal hearts of the Atlantic hagfish, M. glutinosa [237].

In rainbow trout, intra-arterial injections of serotonin $\left(50-250 \mathrm{nmol} \mathrm{kg}^{-1}\right)$ in vivo elicited the dose-dependent release of both catecholamines [93]. Similarly, bolus injections of serotonin $\left(250 \mathrm{nmol} \mathrm{kg}{ }^{-1}\right)$ into an in situ saline-perfused PCV preparation of rainbow trout also resulted in a significant increase in perfusate adrenaline and noradrenaline levels [93]. While the in situ serotonin-induced release of adrenaline in rainbow trout was abolished by pre-treatment with the serotonergic receptor antagonist methysergide, it did not abolish the catecholamine increases in vivo [93]. Serotonin $\left(250 \mathrm{nmol} \mathrm{kg}^{-1}\right)$ also stimulated the secretion of both catecholamines in an in situ preparation of the Atlantic hagfish [25]. In this species, pre-treatment with methysergide abolished the serotonin-mediated release of both catecholamines [25].

Although serotonin is stored in the vicinity of catecholamines and can elicit catecholamine secretion in both rainbow trout and Atlantic hagfish, the physiological conditions under which these serotonin stores may participate in the control of catecholamine release have yet to be established. In situ, the inability of carbachol, a cholinergic agonist, to elicit serotonin release in either the rainbow trout [93] or Atlantic hagfish [25] indicates that, at least in these two species, the release of serotonin in not under cholinergic control. In the Atlantic hagfish, while injections of $\left[\mathrm{Asn}^{1}-\mathrm{Val}^{5}\right]$-angiotensin II elicits the release of serotonin in situ [25], the significance of this observation remains to be confirmed in vivo.

A close association between serotonin stores and catecholamine stores is not a characteristic restricted to fish. In addition to catecholamines, the chromaffin cells of different anuran $[68,69,153]$ and mammalian (see [88] 

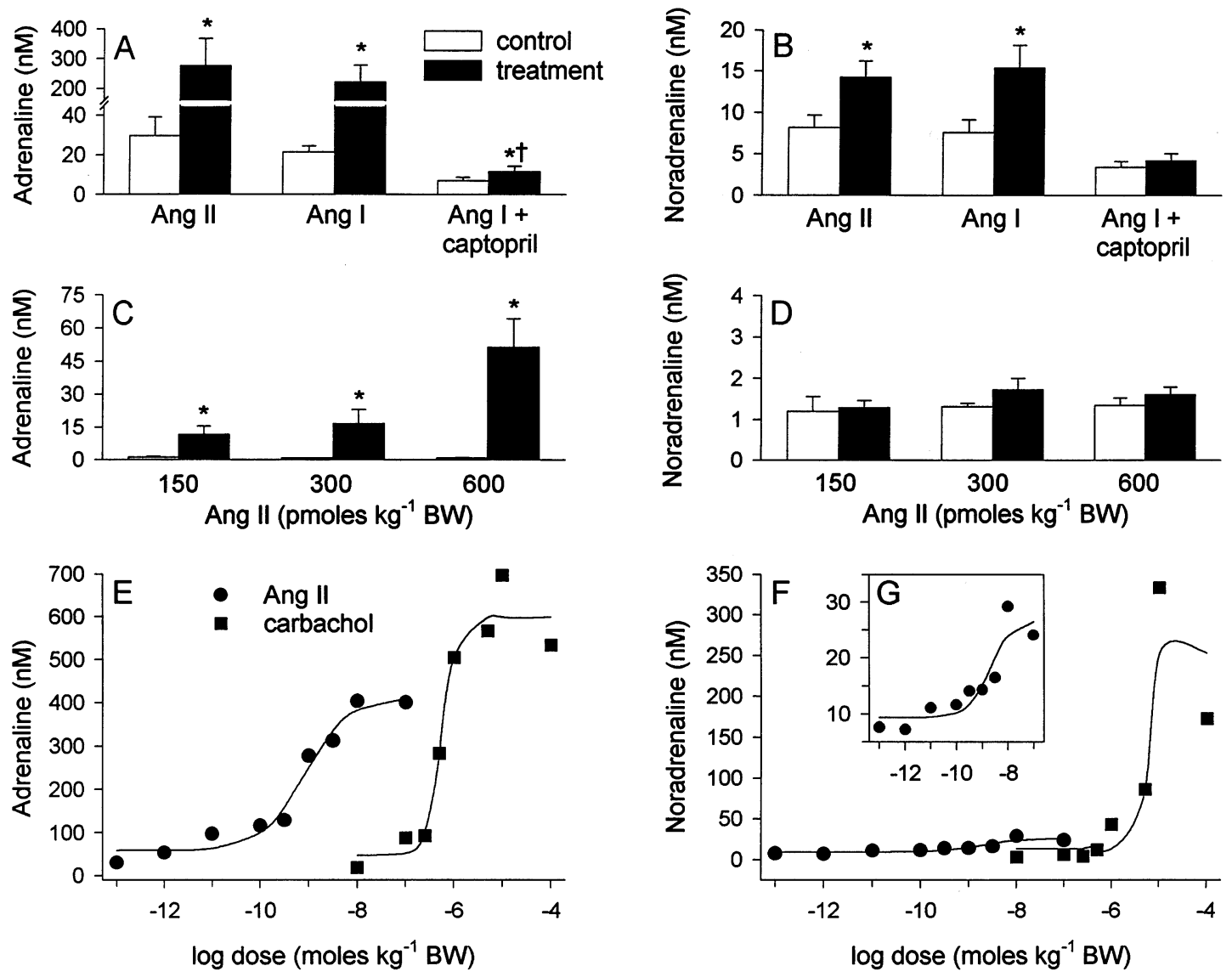

Fig. 4. (A) Perfusate [adrenaline] and (B) [noradrenaline] from in situ head-kidney preparations of $O$. mykiss given a bolus injection of either 1 nmol kg ${ }^{-1}$ body weight (BW) $\left[\mathrm{Asn}^{1}-\mathrm{Val}^{5}\right]$-angiotensin II (Ang II), [Asn $\left.{ }^{1}-\mathrm{Val}^{5}-\mathrm{Asn}^{9}\right]$-angiotensin I (Ang I), or [Asn $\left.{ }^{1}-\mathrm{Val}^{5}-\mathrm{Ass}^{9}\right]$-angiotensin I in fish pre-perfused with the angiotensin converting enzyme inhibitor captopril $\left(10^{-4} \mathrm{~mol}^{-1}\right.$; Ang I + captopril) [25]. (C) Plasma [adrenaline] and (D) [noradrenaline] from O. mykiss given a bolus injection of [Asn $\left.{ }^{1}-\mathrm{Val}^{5}\right]$-angiotensin II (N.J. Bernier and S.F. Perry, unpublished observations) in vivo. The open and solid bars of panels A-D represent control and maximum [catecholamine] in nM before and after the injections of angiotensins, respectively. ${ }^{*}$ Significantly different from the control values for a given treatment. $\dagger$ Significantly different from the response obtained in the Ang I treatment. (E) Dose response curves of perfusate [adrenaline] and (F) perfusate [noradrenaline] as a function of log $\left[\mathrm{Asn}^{1}-\mathrm{Val}^{5}\right.$ ]-angiotensin II (solid circle; [25]) and of the cholinergic agonist carbachol (solid square; C. Montpetit and S.F. Perry, unpublished observations) in in situ head-kidney preparations of O. mykiss. (G) Enlargement of the dose-response curve of perfusate [noradrenaline] as a function of $\log \left[\mathrm{Asn}^{1}-\mathrm{Val}^{5}\right]$-angiotensin II.

for references) species also contain serotonin. In mammals, several studies have attributed direct peripheral catecholamine-releasing effects to serotonin $[73,74,86,236]$. However, although the role of the central serotonergic system in the control of the sympathoadrenal system is well documented [48], the physiological significance of the adrenal serotonergic stores in the control of catecholamine release has yet to be elucidated.

4.2.2.2. Angiotensins. There is considerable evidence that the regulatory peptides of the renin-angiotensin system (RAS), angiotensins, may contribute to the regulation of catecholamine secretion from the chromaffin tissue of the head kidney. Using a bioactive immunohistochemical probe [26], it was demonstrated that the chromaffin tissue of rainbow trout has angiotensin II binding sites which can mediate the stimulatory effects of angiotensin II on catecholamine secretion. However, while bolus injections of the native rainbow trout angiotensin II ([ $\left.\left.\mathrm{Asn}^{1}, \mathrm{Val}^{5}\right]-\mathrm{AngII}\right)$ caused a dose-dependent release of both catecholamines in situ (Fig. 4 A,B), the effects of angiotensin II are more pronounced on adrenaline than on noradrenaline secretion [26]. Angiotensin I also elicits the release of both catecholamines (Fig. 4), however, most of the angiotensin I-elicited catecholamine release is indirect and requires conversion to angiotensin II [26].

Intravascular injections, in vivo, of human angiotensin II ([Asp $\left.{ }^{1}-\mathrm{Il}^{5}\right]$-AngII) in the lumpfish, $C y$ clopterus lumpus [46] and in the dogfish, S. acanthius [207], and of native angiotensin II in rainbow trout (Fig. 4C,D), also elicited an increase in the circulating levels of catecholamines. In rainbow trout, angiotensin II, produced either by the systemic renin-angiotensin system or by a localized renin-angiotensin system in the 
kidney [26], plays an essential role in mediating catecholamine release during hypotensive conditions (N.J. Bernier and S.F. Perry, unpublished observation). Indirect evidence also suggests that angiotensin II may elicit catecholamine release in the bowfin, A. calva [45], and in the American eel, A. rostrata [204,216]. In those species, results of adrenoceptor blockade experiments have shown that the angiotensin II-induced pressor responses are partially mediated by secondary stimulation of the sympathetic nervous system, thereby implying the possible involvement of circulating catecholamines. However, although the pressor response elicited by human angiotensin II in the Atlantic hagfish can also be abolished by adrenergic receptor blockade [46], bolus injections of rainbow trout angiotensin II had no effect on the secretion rate of noradrenaline and adrenaline in an in situ preparation from the hagfish [26].

4.2.2.3. Natriuretic peptides. Although several natriuretic peptides (NP) have been isolated and sequenced from several species of fish ([113]), and natriuretic peptides have a variety of different effects on catecholamine synthesis and release from the mammalian adrenal medulla $[87,150,276]$, the interactions between NP and catecholamine release in fish have only been directly assessed in a few species of fish. In C. carpio, there is both immunohistochemical evidence for the presence of atrial natriuretic peptides (ANP) in the adrenaline-synthesizing cells of the head kidney, and autoradiographic evidence for ANP binding sites in the adrenal tissue [142]. In vitro, perifusion of $C$. carpio head kidney slices with rat ANP $\left(10^{-7} \mathrm{~mol} \mathrm{l}^{-1}\right)$ increases acetylcholine-evoked adrenaline release [142]. These results [142] suggest that ANP may have an autocrine and/or paracrine role in the control of catecholamine secretion in C. carpio. In contrast, however, despite the ability of $\alpha$-adrenergic antagonists to block the hypertensive effect of ANP in the rainbow trout [205], in situ perfusion of the chromaffin tissue of trout with rat ANP $\left(10^{-9} \mathrm{~mol} 1^{-1}\right)$ or trout ventricular natriuretic peptide (VNP; $10^{-9}$ mol $1^{-1}$ ) does not significantly affect basal or carbachol-elicited catecholamine release (J.E. McKendry and S.F. Perry, unpublished observations).

In other vertebrate species ANP has either an inhibitory effect on catecholamine release or no effect at all. In the amphibian Xenopus laevis, basal or Achevoked noradrenaline and adrenaline release was not affected by the addition of rat ANP in vitro, and the injection of rat ANP in vivo had no effect on the circulating catecholamine levels [141]. In the rat adrenal medulla, ANP inhibits spontaneous as well as membrane depolarization- (with $\mathrm{KCl}$ ) evoked noradrenaline release [276]. Similarly, in the perfused bovine adrenal medulla, ANP inhibits the release of catecholamines induced by $\mathrm{KCl}$-depolarizing solutions, Ach, and angiotensin II [87].

4.2.2.4. Adrenocorticotropic hormone and cortisol. Activation of the hypothalamo-pituitary axis and release of adrenocorticotropic hormone (ACTH) into the circulation by the pituitary is an integral part of the primary stress response of fish $[22,71,260]$. ACTH, in addition to stimulating corticosteroid release from the interrenal cells of the head kidney, has also been recently implicated in the control of catecholamine secretion in both the rainbow trout [241] and the Atlantic hagfish $[25,220]$. In rainbow trout, in situ administration of a native pituitary extract elicited the release of adrenaline, but not noradrenaline while porcine ACTH elicited a dose-dependent release of adrenaline and a smaller, non dose-dependent, release of noradrenaline. This ACTHelicited secretion of catecholamines in the trout was unaffected by pre-treatment with the cholinergic receptor antagonist, hexamethonium, or the serotonergic receptor antagonist, methysergide, but was abolished in calcium-free media. Also, cortisol administration in situ does not evoke catecholamine release, suggesting that $\mathrm{ACTH}$ is acting directly on receptors on the chromaffin cell membrane to initiate catecholamine release [241]. Additionally, in rainbow trout, intra-arterial injections of porcine ACTH in vivo caused an elevation of plasma adrenaline but not noradrenaline levels [241].

In the Atlantic hagfish, in situ administration of either an extract of Atlantic cod pituitary [220] or porcine ACTH [25] elicited the release of both catecholamines which was unaffected by pre-treatment with either hexamethonium or methysergide [25]. In contrast to the effects of ACTH in the hagfish and rainbow trout, perifusion of $C$. carpio head kidney slices with ACTH stimulated cortisol secretion but did not affect the release of catecholamines [142].

In rainbow trout, although cortisol does not directly stimulate catecholamine secretion in situ, it has been demonstrated to modulate the cholinergic control of catecholamine release [241]. In trout a chronic elevation of plasma cortisol levels increased the responsiveness of the catecholamine release process in situ to low doses of the cholinoceptor agonist carbachol [241]. In contrast, however, the chromaffin cells of rainbow trout chased twice daily to exhaustion for 5 days, exhibited a decrease in responsiveness to carbachol in situ [238]. Therefore, while cortisol alone may sensitise the responsiveness of the catecholamine release process [241], under conditions of repeated physical stress [238] the effects of cortisol may be marked by other modulators of catecholamine release.

4.2.2.5. Opioid peptides and other bioactive peptides. The presence of opioid peptides in fish chromaffin cells was first demonstrated, using immunohistochemical tech- 
niques, in the posterior cardinal vein and the head kidney of the American eel, A. rostrata [117]. This initial survey revealed methionine-enkephalin, leucineenkephalin, and morphine-like immunoreactivity in the chromaffin tissue [117]. Further experiments with perifused head kidney pieces in this species revealed that, in addition to catecholamines, the chromaffin tissue secretes morphine and its precursor codeine [82]. While both of these endogenous opiates appear to modulate catecholamine secretion in the eel in vitro, the complexity of these interactions and the multiplicity of potential chromaffin cell opiate receptors does not allow for one to draw definitive conclusions regarding a possible autocrine function for these peptides [83].

Enkephalins are also present within the chromaffin cells of several amphibian (see [242] for references), and mammalian (see [75] for references) species. In addition to co-localization with catecholamines, enkephalins are also co-secreted in response to various stimuli (see [64] for references). Opioid binding sites are located on mammalian chromaffin cells, and while several studies have demonstrated that opioids can inhibit nicotinicevoked catecholamine release from the adrenal gland $[50,152]$, other studies have found no role for adrenal opioid peptides in modulating catecholamine secretion (see [171] for references).

In contrast to the aforementioned study [117], another study [237] did not detect any enkephalins (metenkephalin, met-enkephalin-arg ${ }^{6}$-phe ${ }^{7}$, met-enkephalin$\arg ^{6}-\mathrm{gly}^{7}-\mathrm{leu}^{8}$ ) associated with the chromaffin tissue in either the rainbow trout, Atlantic cod, European eel, spiny dogfish or Atlantic hagfish. Indeed, with the exception of immunohistochemical evidence for the presence of neuropeptide Y (NPY) and peptide YY (PYY) in the European eel, the chromaffin cells of the three teleost species did not exhibit a positive labeling reaction for LPLRFamide, FMRFamide, galanin, substance P, somatostatin, or chromogranins [237]. Since several of these bioactive peptides (and others not investigated in this study [237]) are present in the chromaffin cells of different mammalian and amphibian species (see [211] and [237] for references) but absent from a number of fish species, it appears that the content of fish chromaffin cells may be less complex than those found in other vertebrates [237]. However, evidence for the presence of chromogranins in the chromaffin cells of $C$. carpio and M. scorpius has been reported $[243,244]$. Thus, in fish, as in other vertebrates, there appears to be significant species differences in the occurrence and distribution of chromaffin cell associated peptides.

4.2.2.6. Adenosine. In the adrenal medulla of mammals, ATP co-released with catecholamines from chromaffin cells during exocytosis, is degraded to adenosine within the extracellular space [72]. Through an autocrine or paracrine pathway, adenosine, or adenosine agonists, can suppress catecholamine secretion from the adrenal medulla $[51,52,151]$ via specific adenosine receptors on the surface of chromaffin cell [47]. Consequently, adenosine receptor blockade enhances the secretory response elicited by acetylcholine [151].

Although the presence of ATP in fish chromaffin cells, its co-release with catecholamines and breakdown to adenosine in the extracellular space remain to be investigated, there is mounting evidence that adenosine is involved in the control of catecholamine release $[25,27]$. In both $O$. mykiss and E. stouti, pre-treatment with intravascular injections of the adenosine receptor antagonist theophylline, significantly increased the concentration of circulating adrenaline following a hypoxic challenge [27]. In M. glutinosa, in situ perfusion of the systemic heart and PCV with the adenosine receptor agonist NECA, or the antagonist DPSPX, modified the catecholamine secretory responses elicited by ACTH, serotonin, and carbachol [25]. Overall, these experiments in $M$. glutinosa suggest that adenosine may inhibit the release of catecholamines elicited by either serotonin or carbachol, while stimulating those elicited by ACTH [25]. Both the in vivo [27] and in situ [25] results suggest that the modulatory effects of adenosine may be occurring primarily on the adrenaline-storing cells.

4.2.2.7. Histamine. Histamine can elicit a substantial secretory response from the adrenal medulla in several mammalian species $[34,37]$. Indeed, histamine may be the most potent non-cholinergic secretagogue of catecholamines from the isolated bovine adrenal chromaffin cell [37]. To our knowledge, the potential effect of histamine on catecholamine release has yet to be investigated in either teleosts or elasmobranchs. In the Atlantic hagfish, M. glutinosa, perfusion of the chromaffin tissue with histamine concentrations ranging from 0.3 to $300 \mu \mathrm{M}$ did not elicit catecholamine secretion [25].

4.2.2.8. Catecholamines. In the Atlantic cod, G. morhua, the addition of high levels of a particular catecholamine (adrenaline or noradrenaline; $\sim 200 \mathrm{nM}$ ) into the inflowing perfusion fluid of an in situ preparation inhibited the Ach-elicited release of that particular catecholamine [219]. Thus it appears as if each circulating catecholamine in the Atlantic cod may 'auto-inhibit' its own release from the head kidney through a negative feedback control mechanism [219]. In contrast, in the lamprey, P. marinus [65] and the American eel, $A$. rostrata [79], there is in vivo evidence that catecholamines are catecholaminotropic (i.e. can initiate catecholamine release). While only adrenaline caused a dose-related increase of plasma dopamine and noradrenaline in the lamprey [65], each of the three catecholamines stimulated the release of the respective 
other two in $A$. rostrata [79]. In the eel, these catecholaminotropic effects were unaffected by denervation of the chromaffin tissue in the head kidney [116]. In rainbow trout, continuous infusion of adrenaline does not effect the circulating levels of noradrenaline [218]. Also, while adrenaline and dopamine, but not noradrenaline, may be catecholaminotropic in the rat [80], catecholamines do not have such a property in humans [81]. As such, there appear to be complex, and species specific, interactions between circulating catecholamines and the further release of catecholamines from chromaffin tissue.

\subsection{Non-cholinergic neuronal agents}

In addition to acetylcholine, several non-cholinergic neurotransmitters and/or neuromodulators have been identified as potential secretagogues of catecholamines from the chromaffin tissue in vertebrates (see [167] for review). In fish, nerves fibers displaying vasoactive intestinal polypeptide (VIP) and pituitary adenylyl cyclase-activating polypeptide (PACAP) immunoreactivity have been identified in the chromaffin tissue of G. morhua, O. mykiss, A. anguilla, and S. acanthias [237]. In the axillary bodies of the elasmobranch $S$. acanthias, there are also nerve fibers exhibiting substance P-like and galanin-like immunoreactivity [237]. Although the physiological significance of these observations remains speculative, in both mammals and amphibians there is increasing evidence that VIP, PACAP, and tachykinins (the family of peptides which includes substance P) may have the ability to stimulate and/or modulate catecholamine release under physiological conditions $[54,112,145,146,165,167,278,286,302$, 306].

\section{Conclusion}

This review has provided a detailed account of the afferent limb of the adrenergic stress response in fish. The control of catecholamine secretion from chromaffin cells in fish involves a multitude of neurotransmitters, hormones, chemical factors and second messenger systems. The presence of numerous cholinergic and non-cholinergic pathways of release suggests that the chromaffin cell in fish is a complex endocrine/ paracrine cell with the potential for a dynamic and flexible process of secretion capable of responding to numerous environmental or physiological perturbations. Although many of the complexities of the mammalian chromaffin cell have yet to be revealed in fish, clearly there are many similarities in the afferent limb of the adrenergic stress response across the vertebrate lineage.

\section{Acknowledgements}

Financial assistance was provided by NSERC of Canada in the form of scientific and operating grants to SFP. SGR was the recipient of NSERC post-graduate scholarships and a postdoctoral fellowship. NJB was the recipient of an NSERC post-graduate scholarship. Marosh Furimsky provided data from Fig. 1 (C,D,E).

\section{References}

[1] Abelli L, Gallo VP, Civinni A, Mastrolia L. Immunohistochemical and ultrastructural evidence of adrenal chromaffin cell subtypes in sea bass, Dicentrarchus labrax (L.). Gen Comp Endocrinol 1996;102:113-22.

[2] Abrahamsson T. Phenylethanolamine- $N$-methyltransferase (PNMT) activity and catecholamine storage and release from chromaffin tissue of the spiny dogfish, Squalus acanthias. Comp Biochem Physiol C 1979;64:169-72.

[3] Abrahamsson T. The effect of SK and F64139, an inhibitor of phenylethanolamine- $N$-methyltransferase (PNMT), on adrenaline and noradrenaline content in sympathetic neurons of the cod, Gadus morhua. Comp. Biochem Physiol C 1980;67:4954.

[4] Abrahamsson T, Holmgren S, Nilsson S. On the chromaffin system in the lungfish, Protopterus aethiopicus. Acta Physiol Scand 1979;107:135-9.

[5] Abrahamsson T, Jönsson AC, Nilsson S. Catecholamine synthesis in the chromaffin tissue of the African lungfish, Protopterus aethiopicus. Acta Physiol Scand 1979;107:149-51.

[6] Abrahamsson T, Jönsson AC, Nilsson S. Activity of dopamine$\beta$-hydroxylase $(\mathrm{D} \beta \mathrm{H})$ and phenylethanolamine- $N$-methyltransferase (PNMT) in heart, lung and chromaffin tissue from the Florida spotted gar, Lepisosterus platyrhincus (Holostei). Acta Physiol Scand 1981;111:431-3.

[7] Abrahamsson $\mathrm{T}$, Nilsson $\mathrm{S}$. Phenylethanolamine- $N$-methyltransferase (PNMT) activity and catecholamine content in chromaffin tissue and sympathetic neurons in the cod, Gadus morhua. Acta Physiol Scand 1976;96:94-9.

[8] Accordi F. The chromaffin cells of Siren lacertina (Amphibia, Urodela): cytological characteristics and evidence of exocytosis. J Anat 1987;156:169-76.

[9] Accordi F. The adrenal gland of Amphibia tridactylum (Amphibia, Urodela). Comp Endocrinol (Life Sciences Advances) 1988;7:55-8.

[10] Accordi F. The chromaffin cells of urodele amphibians. J Anat 1991;179:1-8.

[11] Accordi F, Gallo VP. Adrenaline-, noradrenaline-, and small granule containing-cells in the adrenal gland of Discoglossus pictus (Amphibia, Anura). J Anat 1982;135:5-12.

[12] Accordi F, Grassi Milano E. Catecholamine-secreting cells in the adrenal gland of Bufo bufo during metamorphosis and in the adult. Gen Comp Endocrinol 1977;33:187-95.

[13] Accordi F, Grassi Milano E, Gallo VP. Adrenal gland of Euproctus (Urodela, salamandridae): comparison among three species and phylogenetic inferences. J Anat 1984;139:209-14.

[14] Aota S, Holmgren KD, Gallaugher P, Randall DJ. A possible role for catecholamines in the ventilatory responses associated with internal acidosis or external hypoxia in the rainbow trout, Oncorhynchus mykiss. J Exp Biol 1990;151:57-70.

[15] Augustinsson KB, Fänge R, Johnels A, Östlund E. Histological, physiological and biochemical studies on the heart of two cyclostomes, hagfish (Myxine) and lamprey (Lampetra). J Physiol 1956;131:257-76. 
[16] Avella M, Masoni A, Bornancin M, Mayer-Gostan N. Gill morphology and sodium influx in the rainbow trout (Salmo gairdneri ) acclimated to artificial freshwater environments. J Exp Zool 1987;241:159-69.

[17] Axelrod J, Reisine TD. Stress hormones: their interaction and regulation. Science 1984;224:452-9.

[18] Axelsson M, Nilsson S. Blood pressure control during exercise in the Atlantic cod, Gadus morhua. J Exp Biol 1986;126:225-36.

[19] Axelsson M, Abe AS, Bicudo JEPW, Nilsson S. On the cardiac control in the South American lungfish, Lepidosiren paradoxa. Comp Biochem Physiol 1989;93A:297-316.

[20] Balashov NV, Fänge R, Govyrin VA, Leont'eva GR, Nilsson S, Prozorovskaya MP. On the adrenergic system of ganoid fish: the beluga, Huso huso (Chondrostei). Acta Physiol Scand 1981;111:435-40.

[21] Ballesta JJ, Borges R, Garcia AG, Hidalgo MJ. Secretory and radioligand binding studies on muscarinic receptors in bovine and feline chromaffin cells. J Physiol 1989;418:411-26.

[22] Balm PHM, Pottinger TG. Corticotrope and melanotrope POMC-derived peptides in relation to interrenal function during stress in rainbow trout (Oncorhynchus mykiss). Gen Comp Endocrinol 1995;98:279-88.

[23] Barton BA, Schreck CB. Fasting and diet content affect stressinduced changes in plasma glucose and cortisol in juvenile Chinook salmon. Prog Fish Culturist 1988;50:16-22.

[24] Belpaire F, Laduron P. Tissue fractionation and catecholamines: III Intracellular distribution of endogenous inhibitors of dopamine- $\beta$-hydroxylase in adrenal medulla. Biochem Pharmacol 1970;19:1223-31.

[25] Bernier NJ, Perry SF. Control of catecholamine and serotonin release from the chromaffin tissue of the Atlantic hagfish. J Exp Biol 1996;199:2485-97.

[26] Bernier NJ, Perry SF. Angiotensins stimulate catecholamine release from the chromaffin tissue of the rainbow trout. Am J Physiol 1997;273:R49-57.

[27] Bernier NJ, Fuentes J, Randall DJ. Adenosine receptor blockade and hypoxia tolerance in rainbow trout and Pacific hagfish: II Effects on plasma catecholamines and erythrocytes. J Exp Biol 1996;199:497-507.

[28] Bernier NJ, Harris J, Lessard J, Randall DJ. Adenosine receptor blockade and hypoxia tolerance in rainbow trout and Pacific hagfish: I Effects on anaerobic metabolism. J Exp Biol 1996;199:485-95.

[29] Betito K, Diorio J, Boska P. Brief cortisol exposure elevates adrenal phenylethanolamine- $N$-methyltransferase after a necessary lag period. Eur J Pharmacol 1993;238:273-82.

[30] Blaschko H. The specific action of L-DOPA decarboxylase. J Physiol London) 1939;96:50-1.

[31] Block M, Pärt P. Increased availability of cadmium to perfused rainbow trout Salmo gairdneri (Richardson) gills in the presence of the complexing agents diethyldithiocarbamate and amylxanthate. Aquat Toxicol 1986;16:1-8.

[32] Bloom G, Östlund E, von Euler US. A specific granular secretory cell in the heart of cyclostomes. Mem Soc Endocrinol 1962;12:255-63.

[33] Bloom G, Östlund E, von Euler US, Lishajko F, Ritzen M, Adams-Ray J. Studies on catecholamine-containing granules of specific cells in cyclostome hearts. Acta Physiol Scand 1961;53(185):1-34.

[34] Borges R. Histamine $\mathrm{H} 1$ receptor activation mediates the preferential release of adrenaline in the rat adrenal gland. Life Sci 1994;54:631-40.

[35] Boutilier RG, Iwama GK, Randall DJ. The promotion of catecholamine release in rainbow trout, Salmo gairdneri, by acute acidosis: Interactions between red cell $\mathrm{pH}$ and haemoglobin oxygen carrying capacity. J Exp Biol 1986;123:145-57.
[36] Boutilier RG, Dobson GP, Hoeger U, Randall DJ. Acute exposure to graded hypoxia in rainbow trout (Salmo gairdneri ): metabolic and respiratory adaptations. Respir Physiol 1988;71:69-82.

[37] Burgoyne RD. Control of exocytosis in adrenal chromaffin cells. Biochem Biophys Acta 1991;1071:174-202.

[38] Burgoyne RD, Morgan A. $\mathrm{Ca}^{2+}$ and secretory-vesicle dynamics. Trends Neurosci 1995;18:191-6.

[39] Burgoyne RD, Morgan A, Robinson I, Cheek TR. Exocytosis in adrenal chromaffin cells. J Anat 1993;183:309-14.

[40] Busacker GP, Chavin W. Uptake, distribution, and turnover of catecholamine radiolabel in the goldfish, Carassius auratus L. Can J Zool 1977;55:1656-70.

[41] Butler PJ, Taylor EW, Capra MF, Davison W. The effect of hypoxia on the levels of circulating catecholamines in the dogfish Scyliorhinus canicula. J Comp Physiol B 1978;127:32530.

[42] Butler PJ, Taylor EW, Davison W. The effects of long term, moderate hypoxia on acid-base balance, plasma catecholamines and possible anaerobic end products in the unrestrained dogfish Scyliorhinus canicula. J Comp Physiol B 1979;132:297-303.

[43] Butler PJ, Metcalfe JD, Ginley SA. Plasma catecholamines in the lesser spotted dogfish and rainbow trout at rest and during different levels of exercise. J Exp Biol 1986;123:409-21.

[44] Butler PJ, Axelsson M, Ehrenström F, Metcalfe JD, Nilsson S. Circulating catecholamines and swimming performance in the Atlantic cod, Gadus morhua. J Exp Biol 1989;141:377-87.

[45] Butler DG, Oudit GY, Cadinouche MZA. Angiotensin I and II, and norepinephrine-mediated pressor responses in an ancient holostean fish, the bowfin (Amia calva). Gen Comp Endocrinol 1995;98:289-302.

[46] Carroll RG, Opdyke DF. Evolution of angiotensin II-induced catecholamine release. Am J Physiol 1982;243:R54-69.

[47] Casado V, Casillas T, Mallol J, Canela EI, Lluis C, Franco R. The adenosine receptors present on the plasma membrane of chromaffin cells are of the $\mathrm{A}_{2 \mathrm{~b}}$ subtype. $\mathrm{J}$ Neurochem 1992;59:425-31.

[48] Chaouloff F. Physiopharmacological interactions between stress hormones and central serotonergic systems. Brain Res Rev 1993;18:1-32.

[49] Cheek TR, Burgoyne RD. Effect of activation of muscarinic receptors on intracellular free calcium and secretion in bovine adrenal chromaffin cells. Biochim Biophys Acta 1985;846:16773 .

[50] Chen YM, Dixon WR. The effect of etorphine on nicotine- and muscarine-induced catecholamine secretion from perfused rat adrenal gland. Life Sci 1990;46:1167-73.

[51] Chern YJ, Herrera M, Kao LS, Westhead EW. Inhibition of catecholamine secretion from bovine chromaffin cells by adenine nucleotides and adenosine. J Neurochem 1987;48:1573-6.

[52] Chern YJ, Bott M, Chu PJ, Lin YJ, Kao LS, Westhead EW. The adenosine analogue $N_{6}$-L-phenylisopropyladenosine inhibits catecholamine secretion from bovine adrenal medulla cells by inhibiting calcium influx. J Neurochem 1992;59:1399_ 404.

[53] Chopin LK, Bennett MB. Cellular ultrastructure and catecholamine histofluorescence of the heart of the Australian Lungfish, Neoceratodus forsteri. J Morphol 1995;223:191-201.

[54] Chowdhury PS, Guo X, Wakade TD, Przywara DA, Wakade AR. Exocytosis from a single rat chromaffin cell by cholinergic and peptidergic neurotransmitters. Neuroscience 1994;59(1):15.

[55] Ciaranello RD, Wooten GF, Axelrod J. Regulation of dopamine- $\beta$-hydroxylase in rat adrenal glands. J Biol Chem 1975;250:3204-11. 
[56] Colleti AE, Olson KR. Catecholamine metabolism by the perfused rainbow trout gill. J Exp Zool 1988;248:177-84.

[57] Collins S, Caron MG, Lefkowitz R. Regulation of adrenergic receptor responsiveness through modulation of gene expression. Annu Rev Physiol 1991;53:497-508.

[58] Coupland RE. The Natural History of the Chromaffin Cell. London: Longman, 1965.

[59] Coupland RE. Observations on the form and size distribution of the chromaffin granules and on the identity of adrenaline and noradrenaline-storing chromaffin cells in vertebrates and man. Mem Soc Endocrinol 1971;19:611-35.

[60] Coupland RE. The chromaffin system. In: Blaschko H, Muscholl E, editors. Handbook of Experimental Pharmacology, vol. 33. Catecholamines. Berlin: Springer, 1972:16-45;

[61] Coupland RE. On the fixation of catecholamines including adrenaline in tissue sections. J Anat 1976;122:403-13.

[62] Coupland RE. Ultrastructural features of the mammalian adrenal medulla. In: Motta PM, editor. Ultrastructure of Endocrine Cells and Tissues. Boston, MA: Nijhoff, 1984.

[63] Cubbeddu LX, Barbella YR, Marrero A, Trifaro J, Israel AS. Circulating pool and adrenal soluble content of dopamine- $\beta$ hydroxylase $(\mathrm{D} \beta \mathrm{H})$, in rats, guinea pigs, dogs and humans: their role in determining acute stress-induced changes in plasma enzyme levels. J Pharmacol Exp Ther 1979;211:271-9.

[64] Damase-Michel C, Giraud P, Portolan G, Montastruc JL, Montastruc P, Tran MA. Effects of insulin on the release of neuropeptide $\mathrm{Y},\left[\mathrm{Met}^{5}\right]$ enkephalin and catecholamines from dog adrenal medulla. Eur J Pharmacol 1994;258:277-9.

[65] Dashow L, Epple A. Effects of exogenous catecholamines on plasma catecholamines and glucose in the sea lamprey, Petromyzon marinus. J Comp Physiol B 1983;152:35-41.

[66] Dashow L, Epple A. Plasma catecholamines in the lamprey: intrinsic cardiovascular messengers? Comp Biochem Physiol C 1985;82:119-22.

[67] Davison W, Axelsson M, Forster M, Nilsson S. Cardiovascular responses to acute handling stress in the Antarctic fish Trematomus bernacchii are not mediated by circulating catecholamines. Fish Physiol Biochem 1995;14:253-7.

[68] Delarue C, Leboulenger F, Morra M, Hery F, Verhofstad A J, Berod A, Denoroy L, Pelletier G, Vaudry H. Immunohistochemical and biochemical evidence for the presence of serotonin in amphibian adrenal chromaffin cells. Brain Res 1988;459:1726.

[69] Delarue C, Becquet D, Idres S, Hery F, Vaudry H. Serotonin synthesis in adrenochromaffin cells. Neuroscience 1992;46(2):495-500.

[70] Derome G, Tseng R, Mercier P, Lemaire I, Lemaire S. Possible muscarinic regulation of catecholamine secretion by cyclic GMP in isolated bovine adrenal chromaffin cells. Biochem Pharmacol 1981;30:855-60.

[71] Donaldson EM. The pituitary-interrenal axis as an indicator of stress in fish. In: Pickering AD, editor. Stress and Fish. London: Academic Press, 1981:11-48.

[72] Douglas WW, Poisner AM, Rubin RP. Efflux of adenine nucleotides from perfused adrenal glands exposed to nicotine and other chromaffin cell stimulants. J Physiol (London) 1965;179:130-7.

[73] Douglas WW, Kanno T, Sampson SR. Effects of acetylcholine and other medullary secretagogues and antagonists on the membrane potential of adrenal chromaffin cells: an analysis employing techniques of tissue culture. J Physiol (London) 1967;188:107-20.

[74] Eble JN, Gowdey CW, Vane JR. Blood concentrations of adrenaline in dogs after intravenous administration of 5-hydroxytryptamine. Nature New Biol 1972;238:254-6.

[75] Edwards AV, Jones CT. Autonomic control of adrenal function. J Anat 1993;183:291-307.
[76] Egginton S. Stress response in two Antarctic teleosts (Chaenocephalus aceratus Lonnberg and Notothenia coriiceps Richardson) following capture and surgery. J Comp Physiol B 1994;164:482-91.

[77] Egginton S. A comparison of the response to induced exercise in red- and white-blooded Antarctic fishes. J Comp Physiol B 1997;167:129-34.

[78] Epple A, Vogel W, Nibbio B. Catecholamines in the head and body blood of eels and rats. Comp Biochem Physiol C 1982;71:111-8.

[79] Epple A, Nibbio B. Catecholaminotropic effects of catecholamines in a teleost fish, Anguilla rostrata. J Comp Physiol B 1985; 155:285-90.

[80] Epple A, Heim K, Vogel H. Single doses of catecholamines in the rat: catecholaminotropic, but not hyperglycemic. Comp Biochem Physiol C 1988;89:83-6.

[81] Epple A, Bertoni JM, Hathaway CB. Physiological doses of epinephrine in the human: chronotropic but not hyperglycemic or catecholaminotropic. J Exp Zool 1989;250:67-72.

[82] Epple A, Navarro I, Horak P, Spector S. Endogenous morphine and codeine: release by the chromaffin cells of the eel. Life Sci 1993;52:117-21.

[83] Epple A, Nibbio B, Spector S, Brinn JE. Endogenous codeine: autocrine regulator of catecholamine release from chromaffin cells. Life Sci 1994;54:695-702.

[84] Evinger MJ, Towle AC, Park DH, Lee P, Joh TH. Glucocorticoids stimulate transcription of the rat phenylethanolamine- $N$ methyltransferase (PNMT) gene in vivo and in vitro. Cell Mol Neurobiol 1992;12(3):193-215.

[85] Falcioni G, Grelloni F, Gabbianelli R, Bonfigli AR, Colosimo A. Adrenaline effects on the oxygen binding to trout haemoglobin. Comp Biochem Physiol C 1991;98:451-3.

[86] Feniuk W, Hare J, Humphrey PPA. An analysis of the mechanism of 5-hydroxytryptamine-induced vasopressor responses in ganglion-blocked anaesthetized dogs. J Pharm Pharmacol 1980;33:155-60.

[87] Fernandez BE, Dominguez AE, Gonzalez MA, Okobori R. Role of atrial natriuretic peptide on calcium channel mechanisms involved in catecholamine release from bovine adrenal medulla. Arch Int Pharmacodyn 1992;316:105-13.

[88] Fernandez-Vivero J, Rodriguez-Sanchez F, Verastequi C, Moriano FC, Romero A, de Castro JM. Immunocytochemical distribution of serotonin and neuropeptide $\mathrm{Y}$ (NPY) in mouse adrenal gland. Histol Histopathol 1993;8:509-20.

[89] Fievet B, Caroff J, Motais R. Catecholamine release controlled by blood oxygen tension during deep hypoxia in trout: effect on red blood cell $\mathrm{Na} / \mathrm{H}$ exchanger activity. Respir Physiol 1990;79:81-90.

[90] Forsberg EJ, Rojas E, Pollard HB. Muscarinic receptor enhancement of nicotinic-induced catecholamine secretion may be mediated by phosphoinositide metabolism in bovine adrenal chromaffin cells. J Biol Chem 1986;261:4915-20.

[91] Fritsche R, Nilsson S. Autonomic nervous control of blood pressure and heart rate during hypoxia in the cod, Gadus morhua. J Comp Physiol 1990;160:287-92.

[92] Fritsche R, Nilsson S. Cardiovascular and ventilatory control during hypoxia. In: Rankin JC, Jensen FB, editors. Fish Ecophysiology. London: Chapman and Hall, 1993:180-206.

[93] Fritsche R, Reid SG, Thomas S, Perry SF. Serotonin-mediated release of catecholamines in the rainbow trout, Oncorhynchus mykiss. J Exp Biol 1993;178:191-204.

[94] Fuchs DA, Albers C. Effects of adrenaline and blood gas conditions on red cell volume and intraerythrocytic electrolytes in the carp, Cyprinus carpio. J Exp Biol 1988;137:457-77.

[95] Fuller RW, Hunt JM. Substrate specificity of phenylethanolamine- $N$-methyltransferase. Biochem Pharmacol 1965;14:1896-7. 
[96] Fuller RW, Hunt JM. Inhibition of phenylethanolamine- $N$ methyltransferase by its product, epinephrine. Life Sci. 1967;6:1107-12.

[97] Fuller RW, Roush BW. Substrates and inhibitors of phenylethanolamine- $N$-methyltransferase from human adrenal glands. Int J Biochem 1972;3:225-8.

[98] Fujiwara N, Warashina A, Shimoji K. Characterization of low $\mathrm{pH}$-induced catecholamine secretion in the rat adrenal medulla. J Neurochem 1994;62:1809-15.

[99] Furimsky M, Moon TW, Perry SF. Calcium signalling in isolated single chromaffin cells of the rainbow trout (Oncorhynchus mykiss). J Comp Physiol 1997;166(6):396-404.

[100] Gallo VP, Civinini A, Mastrolia L, Leitner G, Porta S. Cytological and biochemical studies on chromaffin cells in the head kidney of Gasterosteus aculeatus (Teleostei, Gasterosteidae). Gen Comp Endocrinol 1993;92:13-142.

[101] Gamperl AK, Vijayan MM, Boutilier RG. Experimental control of stress hormone levels in fishes: techniques and applications. Rev Fish Biol Fish 1994;4:215-55.

[102] Gershengorn MC. Excessive stimulation is bad, so desensitization is ubiquitous - editorial. Endocrinology 1994;134:5-6.

[103] Giacomini E. Sulla esistenza della sostanza midollare nelle capsule surrenale del Teleostei. Monit Zool Ital 1902;13:183-9.

[104] Giacomini E. Contributo alla conscenza delle capsule surrenale dei Ganoidi e particularmente sull'esistenza delle coro sostanza midollare. Monit Zool Ital 1905;15:19-32.

[105] Giacomini E. Sulle capsule surrenali e sul simpatico dei Dipnoi: Ricerche in Protopterus annectens. RC Acad Lincei 1906; $15: 394-8$

[106] Giacomini E. Anatomia microscopica e sviluppo del sistema interrenale e del sistema cromaffines (sistema feocromo) dei Salmonidi. I. Anatomia microscopica. Mem R Accad Scienze dell'Istituto di Bologna. Classe di Scienze fisiche, Serie 6 . 1912:8;367-387.

[107] Giacomini E. Sul sistema interrenale e sul sistema chromaffine di alcuni Teleostei abissali (Argyropelecuse scopelus). RC Accad Bologna. Classe di Scienza Fisiche, Nuova Serie 1921:25;130 135.

[108] Grassi Milano E, Accordi F. Comparative morphology of the adrenal gland of anuran amphibia. J Anat 1983;136:165-74.

[109] Grassi Milano E, Accordi F. Evolutionary trends in the adrenal gland of anurans and urodeles. J Morphol 1986;189:249-59.

[110] Greco AM, Gilmour KM, Fenwick JC, Perry SF. The effects of softwater acclimation on respiratory gas transfer in the rainbow trout, Oncorhynchus mykiss. J Exp Biol 1995;198(12):2557-67.

[111] Greco AM, Fenwick JC, Perry SF. The effects of softwater acclimation on gill morphology in the rainbow trout, Oncorhynchus mykiss. Cell Tissue Res 1996;285(1):75-82.

[112] Guo X, Wakade AR. Differential secretion of catecholamines in response to peptidergic and cholinergic transmitters in rat adrenals. J Physiol 1994;475(3):539-45.

[113] Hagiwara H, Hirose S, Takei Y. Natriuretic peptides and their receptors. Zool Sci 1995;12:141-9.

[114] Hartman FA, Knouff RA, McNutt AW, Carver JE. Chromaffin pattern in bird adrenals. Anat Rec 1947;97:211-21.

[115] Hathaway CB, Epple A. The sources of plasma catecholamines in the American eel, Anguilla rostrata. Gen Comp Endocrinol 1989;74:418-30.

[116] Hathaway CB, Brinn JE, Epple A. Catecholamine release by catecholamines in the eel does not require the presence of brain or anterior spinal cord. J Exp Zool 1989;249:238-42.

[117] Hathaway CB, Epple A. Catecholamines, opioid peptides, and true opiates in the chromaffin cells of the eel: immunohistochemical evidence. Gen Comp Endocrinol 1990;79:393-405.

[118] Hausdorff WP, Caron MG, Lefkowitz RJ. Turning off the signal-desensitization of beta-adrenergic receptor function. FASEB J 1990;4(11):2881-9.
[119] Hiremagalur B, Nankova B, Nitahara J, Zeman R, Sabban EL. Nicotine increases expression of tyrosine hydroxylase gene. J Biol Chem 1993;268:23704-11.

[120] Holk K, Lykkeboe G. Catecholamine-induced changes in oxygen affinity of carp and trout blood. Respir Physiol 1995; 100:55-62.

[121] Holmes W. The adrenal homologues in the lungfish Protopterus. Proc R Soc London Ser B 1950;137:549-65.

[122] Holtz P. Dopadecarboxylase. Naturwissenschaften 1939;43:724-5.

[123] Hyde DA, Perry SF. Absence of red blood cell pH and oxygen content regulation in American eel (Anguilla rostrata) during hypercapnic acidosis in vivo and in vitro. J Comp Physiol B 1990;159:687-93.

[124] Itoh A, Miwa S, Koshimura K, Akiyama Y, Takagi Y, Yamagata S, Kikuchi $\mathrm{H}$, Masaki T. Ischemia-induced changes in catecholamine release and their mechanisms: a study using cultured bovine adrenal chromaffin cells. Brain Res 1994;643:266-75.

[125] Iwama GK, Boutilier RG, Heming TA, Randall DJ, Mazeaud M. The effects of altering gill water flow on gas transfer in rainbow trout. Can J Zool 1987;65:2466-70.

[126] Iwama GK, McGeer JC, Pawluk MP. The effects of five fish anaesthetics on acid-base balance, hematocrit, blood gases, cortisol and adrenaline in rainbow trout. Can $\mathbf{J}$ Zool 1989;67:2065-73.

[127] Jensen D. Cardioregulation in an aneural heart. Comp Biochem Physiol 1961;2:181-201

[128] Jensen D. The aneural heart of hagfish. Ann NY Acad Sci 1965;127:443-58.

[129] Jiang W, Uht R, Bohn MC. Regulation of phenylethanolamine $N$-methyltransferase (PNMT) mRNA in the rat adrenal medulla by corticosterone. Int J Dev Neurosci 1989;7:513-20.

[130] Johnels AG, Palmgren A. 'Chromaffin' cells in the heart of Myxine glutinosa. Acta Zool Bb XLI 1960:314-314.

[131] Jönsson AC. On the synthesis of catecholamines in chromaffin tissue of fish. Ph.D. Thesis, University of Göteborg: Department of Zoophysiology, 1982.

[132] Jönsson AC. Dopamine- $\beta$-hydroxylase activity in the axillary bodies, the heart and the splanchnic nerve in two elasmobranchs, Squalus acanthias and Etmopterus spinax. Comp Biochem Physiol C 1982;71:191-4.

[133] Jönsson AC. Catecholamine formation in vitro in the systemic and portal hearts of the Atlantic hagfish, Myxine glutinosa. Mol Physiol 1983;3:297-304.

[134] Jönsson AC, Nilsson S. Effect of $\mathrm{pH}$, temperature and $\mathrm{Cu}^{2+}$ on the activity of dopamine- $\beta$-hydroxylase from the chromaffin tissue of the cod, Gadus morhua. Comp Biochem Physiol C 1979;62:5-8.

[135] Jönsson AC, Nilsson S. Axonal transport and subcellular distribution of dopamine- $\beta$-hydroxylase in the cod, Gadus morhua. Acta Physiol Scand 1981;111:441-5.

[136] Jönsson AC, Nilsson S. Catecholamine biosynthesis in vitro and in vivo in the chromaffin tissue of the Atlantic cod, Gadus morhua. Comp Biochem Physiol C 1983;75:43-6.

[137] Jönsson AC, Wahlqvist I, Hansson T. Effects of hypophysectomy and cortisol on the catecholamine biosynthesis and catecholamine content in chromaffin tissue from rainbow trout, Salmo gairdneri. Gen Comp Endocrinol 1983;51:278-85.

[138] Kakuta I, Murachi S. Renal responses to hypoxia in carp, Cyprinus carpio - changes in glomerular filtration rate, urine and blood properties and plasma catecholamines of carp exposed to hypoxic conditions. Comp Biochem Physiol A. 1992;103:259-67.

[139] Kao LS, Ho MY, Cragoe EJJ. Intracellular $\mathrm{pH}$ and catecholamine secretion from bovine adrenal chromaffin cells. J Neurochem 1991;57:1656-60. 
[140] Kinkead R, Fritsche R, Perry SF, Nilsson S. The role of circulating catecholamines in the ventilatory and hypertensive responses to hypoxia in the Atlantic cod (Gadus morhua). Physiol Zool 1991;64:1087-109.

[141] Kloas W, Hanke W. Effects of atrial natriuretic factor on corticosteroid and catecholamine secretion by the adrenals of Xenopus laevis. Gen Comp Endocrinol 1992;85:269-77.

[142] Kloas W, Reinecke M, Hanke W. Role of the atrial natriuretic peptide for adrenal regulation in the teleost fish Cyprinus carpio. Am J Physiol 1994;267:R1034-42.

[143] Knight DE, Baker PF. Observations on the muscarinic activation of catecholamine secretion in the chicken adrenal. Neuroscience 1986;19:357-66.

[144] Kobayashi S, Coupland RE. Morphological aspects of chromaffin tissue: the differential fixation of adrenaline and noradrenaline. J Anat 1993;183:223-36.

[145] Kodjo MK, Leboulenger F, Conlon JM, Vaudry H. Effect of ranakinin, a novel tachykinin, on cytosolic free calcium in frog adrenochromaffin cells. Endocrinology 1995;136:4535-42.

[146] Kodjo MK, Leboulenger F, Porcedda P, Lamacz M, Conlon J M, Pelletier G, Vaudry H. Evidence for the involvement of chromaffin cells in the stimulatory effect of tachykinins on corticosteroid secretion by the frog adrenal gland. Endocrinology 1995;136:3253-9.

[147] Kohn A. Das chromaffin Gewebe. Ergerb Anat Entwicklungsgesch 1902;12:253-348.

[148] Kruger C, Haunstetter A, Gerber S, Serf C, Kaufmann A, Kubler W, Haass M. Nicotine-induced exocytotic norepinephrine release in guinea-pig heart, human atrium and bovine adrenal chromaffin cells: modulation by single components of ischaemia. J Mol Cell Cardiol 1995;27:1491-506.

[149] Kuchel O. Stress and catecholamines. In: Jasmin G, Cantin M, editors. Stress revisited. I. Neuroendocrinology of Stress. Methods Achieve. Exp Pathol, vol. 14. Basel: Karger; 1991:80-103.

[150] Kuchel O, Debinski W, Racz K, Buu NT, de Lean A, Garcia $\mathrm{R}$, Cantin M, Genest J. Atrial natriuretic factor is an inhibitory modulator of peripheral sympathoadrenomedullary activity. In: Brenner BM, Laragh JHL, editors. Biologically Active Atrial Peptides. Am Soc Hypertens Symp Ser 1 New York: Raven Press, 1987:318-321.

[151] Kumakura K. Possible involvement of ATP and its metabolites in the function of adrenal chromaffin cells. In: Hanin I, editor. Dynamics of Neurotransmitter Function. New York:Raven Press, 1984:271-280.

[152] Kumakura K, Karoum F, Guidotti A, Costa E. Modulation of nicotinic receptors by opiate receptor agonists in cultured chromaffin cells. Nature 1980;283:489-92.

[153] Kuramoto H. An immunohistochemical study of chromaffin cells and nerve fibers in the adrenal gland of the bullfrog, Rana catesbeiana. Arch Histol Jap 1987;50(1):15-38.

[154] Larsson A, Lewander K. Metabolic effects of starvation in the eel Anguilla anguilla L. Comp Biochem Physiol A 1973;44:36774.

[155] Laurent P, Hebibi N. Gill morphology and fish osmoregulation. Can J Zool 1989;67:3055-63.

[156] Laurent P, Hobe H, Dunnel-Erb S. The role of environmental sodium chloride relative to calcium in gill morphology of freshwater salmonid fish. Cell Tissue Res 1985;240:675-92.

[157] Laurent P, Dunnel-Erb S, Chevalier C, Lignon J. Gill epithelial cell kinetics in a freshwater teleost, Oncorhynchus mykiss, during adaptation to ion-poor water and hormonal treatments. Fish Physiol Biochem 1995;13:353-70.

[158] Leatherland JF, Farbridge KJ. Chronic fasting reduces the response of the thyroid to growth hormone and $\mathrm{TSH}$, and alters the growth hormone-related changes in hepatic 5'monodeiodinase activity in rainbow trout, Oncorhynchus mykiss. Gen Comp Endocrinol 1992;87:342-53.
[159] Ledbetter FH, Kirshner N. Studies of chick adrenal medulla in organ culture. Biochem Pharmacol 1975;24:967-74.

[160] Le Douarin N. The Neural Crest. Cambridge University Press: Cambridge, 1982.

[161] Lee K, Sekine A. Effects of hypoxia on stimulus-release coupling mechanisms in cultured bovine adrenal chromaffin cells. Naunyn-Schmiedeberg's Arch Pharmacol 1993;348:275-81.

[162] Lee K, Miwa S, Koshimura K, Hasegawa H, Hamahata K, Fujiwara M. Effects of hypoxia on the catecholamine release, $\mathrm{Ca}^{2+}$ uptake, and cytosolic free $\mathrm{Ca}^{2+}$ concentration in cultured bovine adrenal chromaffin cells. J Neurochem 1990;55:1131-7.

[163] Lee K, Ito A, Koshimura K, Ohue T, Takagi Y, Miwa S. Differential effects of hypoxia on ligand binding properties of nicotinic and muscarinic acetylcholine receptors on cultured bovine chromaffin cells. J Neurochem 1995;64:874-82.

[164] Leino RL, McCormick JH. Morphological and morphometric changes in chloride cells of the gills of Pimephales promelas after chronic exposure to acid water. Cell Tissue Res. 1984;236:121-8.

[165] Lesouhaitier O, Esneu M, Kodjo MKL, Hamel C, Contesse V, Yon L, Remy-Jouet I, Fasolo A, Fournier A, Vandesande F, Pelletier G, Conlon JM, Roubos EW, Feuilloley M, Delarue C, Leboulenger F, Vaudry H. Neuroendocrine communication in the frog adrenal. Zool Sci 1995;12:255-64.

[166] Liang BT, Perlman RL. Catecholamine secretion by hamster adrenal cells. J Neurochem 1979;32:927-33.

[167] Livett BG, Marley PD. Noncholinergic control of adrenal catecholamine secretion. J Anat 1993;183:277-89.

[168] Loughna PT, Goldspink G. The effects of starvation on protein turnover in red and white myotomal muscle of rainbow trout, Salmo gairdneri Richardson. J Fish Biol 1984;25:223-30.

[169] Lowe TE, Wells RMG. Primary and secondary responses to line capture in the blue Mao mao. J Fish Biol 1996;49:287-300.

[170] Lutz BR, Wyman LC. The chromaphil tissue and interrenal bodies of elasmobranchs and the occurrence of adrenin. J Exp Zool 1927;47:295-307.

[171] Marley PD, Livett BG. Effects of opioid compounds on desensitization of the nicotinic response of isolated bovine adrenal chromaffin cells. Biochem Pharmacol 1987;36(18):2937-44.

[172] Mastrolia L, Gallo V P, La Marca A. Adrenal homologue in Scardinius erythrophthalmus (Teleosti, Cyprinidae): light and electron microscopic observations. Bull Zool 1981;48:127-38.

[173] Mastrolia L, Gallo VP, La Marca A. The adrenal chromaffin cells of Salmo gairdneri Richardson (Teleostei, Salmonidae). J Anat 1984;138:503-11.

[174] Mastrolia L, Gallo VP, Manelli H. On the chromaffin cells in fish adrenals. In: Abstracts, XI International Symposium on Comparative endocrinology. Malaga, Spain, 1989.

[175] Mazeaud MM. Epinephrine biosynthesis in Petromyzon marinus (cyclostoma) and (Salmo gairdneri teleost). Comp Gen Pharmacol 1972;3:457-68.

[176] Mazeaud MM, Mazeaud F, Donaldson EM. Primary and secondary effects of stress in fish: Some new data with a general review. Trans Am Fish Soc 1977;106:201-12.

[177] Metcalfe JD, Butler PJ. The use of $\alpha$-methyl- $p$-tyrosine to control circulating catecholamines in the dogfish Scyliorhinus canicula: the effects on gas exchange in normoxia and hypoxia. J Exp Biol 1989;141:21-32.

[178] Milligan CL, Wood CM. Regulation of blood oxygen transport and red cell $\mathrm{pHi}$ after exhaustive exercise in rainbow trout (Salmo gairdneri) and starry flounder (Platichthys stellatus). J Exp Biol 1987;133:263-82.

[179] Molinoff PB, Axelrod J. Biochemistry of catecholamines. Ann Rev Biochem 1971;40:465-500.

[180] Mommsen TP, Walsh PJ, Perry SF, Moon TW. Interactive effects of catecholamines and hypercapnia on glucose produc- 
tion in isolated trout hepatocytes. Gen Comp Endocrinol 1988;70:63-73.

[181] Moon TW, Mommsen TP. Vasoactive peptides and phenylephrine actions in isolated trout hepatocytes. Am J Physiol 1990;259:E649-64.

[182] Moon TW, Walsh PJ, Mommsen TP. Fish hepatocytes: a model metabolic system. Can J Fish Aqu Sci 1985;42:1772-82.

[183] Moon TW, Foster GD, Plisetskaya EM. Changes in peptide hormones and liver enzymes in the rainbow trout deprived of food for 6 weeks. Can J Zool 1989;67:2189-93.

[184] Motais R, Scheuring F, Borgese F, Garcia-Romeu, F. Characteristics of $\beta$-adrenergic-activated $\mathrm{Na}^{+}$-proton transport in red blood cells. In: Ritchie JM, Magistretti PJ, Bolis L, editors. Progress in Cell Research, vol 1. Amsterdam: Elsevier, 1990:179-193.

[185] Mueller RA, Thoenen H, Axelrod J. Adrenal tyrosine hydroxylase: compensatory increase in the activity after chemical sympathectomy. Science 1969;163:468-9.

[186] Mueller RA, Thoenen H, Axelrod J. Increase in tyrosine hydroxylase activity after reserpine treatment. J Pharm Exp Ther 1969;169:74-9.

[187] Mueller RA, Thoenen H, Axelrod J. Effect of pituitary and ACTH on the maintenance of basal tyrosine hydroxylase activity in the rat adrenal gland. Endocrinology 1970;86:751-5.

[188] Nakano T, Tomlinson N. Catecholamine and carbohydrate concentrations in rainbow trout (Salmo gairdneri) in relation to physical disturbances. J Fish Res Bd Can 1967;24:1701-15.

[189] Nandi J. New arrangement of internal and chromaffin tissues of teleost fish. Science 1961;134:389-90.

[190] Nekvasil NP, Olson KR. Localization of ${ }^{3} \mathrm{H}$-norepinephrine binding sites in the trout gill. J Exp Zool 1985;235:309-13.

[191] Nekvasil NP, Olson KR. Plasma clearance, metabolism and tissue accumulation of ${ }^{3} \mathrm{H}$-labeled catecholamines in trout. Am J Physiol 1986;259:R519-25.

[192] Nekvasil NP, Olson KR. Extraction and metabolism of circulating catecholamines by the trout gill. Am J Physiol 1986;250:R526-31.

[193] Nikinmaa M. Adrenergic regulation of haemoglobin oxygen affinity in rainbow trout red cells. J Comp Physiol 1983;259B:R519-25.

[194] Nikinmaa M. Vertebrate red blood cells. Zoophysiology, vol 28. Berlin: Springer-Verlag, 1990.

[195] Nikinmaa M. Membrane transport and control of haemoglobin-oxygen affinity in nucleated erythrocytes. Physiol Rev 1992;72:301-21.

[196] Nilsson GE. Effects of anoxia on catecholamine levels in brain and kidney of the crucian carp. Am J Physiol 1989;257:R10-4.

[197] Nilsson GE. Long-term anoxia in the crucian carp: changes in the levels of amino acid and monoamine neurotransmitters in the brain, catecholamines in the chromaffin tissue, and liver glycogen. J Exp Biol 1990;150:295-320.

[198] Nilsson GE, Block M. Decreased norepinephrine and epinephrine contents in the chromaffin tissue of the rainbow trout (Oncorhynchus mykiss) exposed to diethyldithiocarbamate and amylxanthate. Comp Biochem Physiol C 1991;98:391-4.

[199] Nilsson S. Fluorescent histochemistry and cholinesterase staining of sympathetic ganglia in a teleost, Gadus morhua. Acta Zool (Stockholm) 1976;57:69-77.

[200] Nilsson S. On the adrenergic system of ganoid fish: the Florida spotted gar, Lepisosteus platyrhincus (Holostei). Acta Physiol Scand 1981;111:447-54.

[201] Nilsson, S. Autonomic Nerve Function in Vertebrates. Zoophysiology, vol. 13. Berlin: Springer-Verlag, 1983.

[202] Nilsson S. Review-adrenergic control systems in fish. Mar Biol Lett 1984;5:127-46.

[203] Nilsson S, Abrahamsson T, Grove DJ. Sympathetic nervous control of adrenaline release from the head kidney of the cod, Gadus Morhua. Comp Biochem Physiol C 1976;55:123-7.
[204] Nishimura H, Norton VM, Bumpus FM. Lack of specific inhibition of angiotensin II in eels by angiotensin antagonists. Am J Physiol 1978;235:H95-H103.

[205] Olson KR, Duff DW. Cardiovascular and renal effects of eel and rat atrial natriuretic peptide in rainbow trout, Salmo gairdneri. J Comp Physiol B 1992;162:408-15.

[206] Opdyke DF, Carroll RC, Keller NE. Systemic arterial pressor responses induced by potassium in dogfish, Squalus acanthias. Am J Physiol 1981;241:R228-32.

[207] Opdyke DF, Carroll RG, Keller NE, Taylor AA. Angiotensin II releases catecholamines in dogfish. Comp Biochem Physiol C 1981;70:131-4.

[208] Opdyke DF, Carroll RG, Keller NE. Catecholamine release and blood pressure changes induced by exercise in dogfish. Am J Physiol 1982;242:R306-10.

[209] Opdyke DF, Bullock J, Keller NE, Holmes K. Dual mechanism for catecholamine secretion in the dogfish shark Squalus acanthias. Am J Physiol 1983;244:R641-5.

[210] Opdyke DF, Carroll RG, Keller NE, Holmes K. Effect of ganglionic blockade on catecholamine secretion in exercised dogfish. Am J Physiol 1983;245:R915-9.

[211] Orezzoli AA, Nicolini VG, Bilinski M, Villar MJ, Hokfelt T, Tramezzani JH. Immunohistochemical localization of neurotensin in a subpopulation of noradrenergic chromaffin cells of the adrenal band of the flat snake (Waglerophis merremii). Gen Comp Endocrinol 1995;97:179-87.

[212] Östlund E. The distribution of catecholamines in lower animals and their effect on the heart. Acta Physiol Scand 1954;31(112):1-67.

[213] Östlund E, Bloom G, Adams-Ray J, Ritzen M, Siegman M, Nordenstam H, Lishajko F, von Euler US. Storage and release of catecholamines, and the occurrence of a specific submicroscopic granulation in hearts of cyclostomes. Nature 1960;188:324-5.

[214] Ottolenghi C, Puviana AC, Gravioli ME, Brighenti L. Epinephrine effect on carbohydrate metabolism in isolated and perfused catfish liver. Gen Comp Endocrinol 1985;59:219-29.

[215] Ottolenghi C, Puviana AC, Gravioli ME, Brighenti L. Epinephrine effect on glycogen phosphorylase activity in catfish liver and muscles. Gen Comp Endocrinol 1986;61:469-75.

[216] Oudit GY, Butler DG. Angiotensin II and cardiovascular regulation in a freshwater teleost, Anguilla rostrata LeSueur. Am J Physiol 1995;269:R726-35.

[217] Parker TL, Kesse WK, Mohamed AA, Afework M. The innervation of the mammalian adrenal gland. J Anat 1993;183:26576.

[218] Perry SF, Vermette MG. The effects of prolonged epinephrine infusion on the physiology of the rainbow trout, Salmo gairdneri. I. Blood respiratory, acid-base and ionic states. J Exp Biol 1987;128:235-53.

[219] Perry SF, Fritsche R, Kinkead R, Nilsson S. Control of catecholamine release in vivo and in situ in the Atlantic cod (Gadus morhua) during hypoxia. J Exp Biol 1991;155:549-66.

[220] Perry SF, Fritsche R, Thomas S. Storage and release of catecholamines from the chromaffin tissue of the Atlantic hagfish Myxine glutinosa. J Exp Biol 1993;183:165-84.

[221] Perry SF, Kinkead R. The role of catecholamines in regulating arterial oxygen content during acute hypercapnic acidosis in rainbow trout (Salmo gairdneri). Respir Physiol 1989;77:36578.

[222] Perry SF, Kinkead R, Gallaugher P, Randall DJ. Evidence that hypoxemia promotes catecholamine release during hypercapnic acidosis in rainbow trout (Salmo gairdneri). Respir Physiol 1989;77:351-64.

[223] Perry SF, Laurent P. Adaptational responses of rainbow trout to lowered external $\mathrm{NaCl}$ concentration: contribution of the branchial chloride cell. J Exp Biol 1989;147:147-68. 
[224] Perry SF, Malone S, Ewing D. Hypercapnic acidosis in the rainbow trout (Salmo gairdneri): I. Branchial ionic fluxes and blood acid-base status. Can J Zool 1987;65:888-95.

[225] Perry SF, Reid SD. Relationship between blood oxygen content and catecholamine levels during hypoxia in rainbow trout and American eel. Am J Physiol 1992;263:R240-9.

[226] Perry SF, Reid SG. The effects of acclimation temperature on the dynamics of catecholamine release in the rainbow trout, Oncorhynchus mykiss. J Exp Biol 1994;186:289-307.

[227] Perry SF, Reid SG. Injection techniques. In: Hochachka PW, Mommsen TP, editors. Biochemistry and Molecular Biology of Fishes, vol. 3. Amsterdam: Elsevier, 1994:85-92.

[228] Perry SF, Reid SG, Salama A. The effects of repeated physical stress on the $\beta$-adrenergic response of the rainbow trout red blood cell. J Exp Biol 1996;199:549-62.

[229] Perry SF, Reid SG, Wankiewicz E, Iyer V, Gilmour KM. Physiological responses of rainbow trout (Oncorhynchus mykiss) to prolonged exposure to softwater. Physiol Zool 1996;69(6):1419-41.

[230] Perry SF, Wood CM. Kinetics of branchial calcium uptake in the rainbow trout: effects of acclimation to various external calcium levels. J Exp Biol 1985;116:411-33.

[231] Perry SF, Wood CM. Control and coordination of gas transfer in fishes. Can J Zool 1989;67:2961-70.

[232] Petterson K, Nilsson S. Nervous control of the branchial vascular resistance of the Atlantic cod, Gadus morhua. J Comp Physiol 1979;129:179-83.

[233] Pickering AD, Pottinger TG, Sumpter JP, Carragher JF, Le Bail PY. Effects of acute and chronic stress on the levels of circulating growth hormone in the rainbow trout, Oncorhynchus mykiss. Gen Comp Endocrinol 1991;83:86-93.

[234] Primmett DRN, Randall DJ, Mazeaud M, Boutilier RG. The role of catecholamines in erythrocyte $\mathrm{pH}$ regulation and oxygen transport in rainbow trout (Salmo gairdneri) during exercise. $\mathbf{J}$ Exp Biol 1986;122:139-48.

[235] Randall DJ, Perry SF. Catecholamines. In: Hoar WS, Randall DJ, Farrell AP, editors. Fish Physiology, vol XIIB. New York: Academic Press, 1992:255-300.

[236] Reid G. Circulatory effects of 5-hydroxytryptamine. J Physiol 1952;118:435-53.

[237] Reid SG, Fritsche R, Jönsson AC. Immunohistochemical localization of bioactive peptides and amines associated with the chromaffin tissue of five species of fish. Cell Tissue Res 1995;280:499-512.

[238] Reid SG, Furimsky M, Perry SF. The effects of repeated physical stress or fasting on catecholamine storage and release in the rainbow trout, Oncorhynchus mykiss. J Fish Biol 1994;45:365-78.

[239] Reid SG, Perry SF. Storage and differential release of catecholamines in rainbow trout (Oncorhynchus mykiss) and American eel (Anguilla rostrata). Physiol Zool 1994;67:216-37.

[240] Reid SG, Perry SF. Cholinergic release of catecholamines from chromaffin cells in the American eel (Anguilla rostrata) is mediated exclusively through the nicotinic receptor. J Comp Physiol 1996;165(6):464-70.

[241] Reid SG, Vijayan MM, Perry SF. Modulation of catecholamine storage and release by the pituitary-interrenal axis in the rainbow trout. J Comp Physiol 1996;165(8):665-76.

[242] Reinecke M, Heym C, Forssmann WG. Distribution patterns and coexistence of neurohormonal peptides (ANP, BNP, NPY, SP, CGRP, enkephalins) in chromaffin cells and nerve fibers of the anuran adrenal organ. Cell Tissue Res 1992;268:247-56.

[243] Reinecke M, Maake C. A phylogenetic survey of pancreastatin and chromogranin immunoreactivity in chromaffin (TH-, $\mathrm{D} \beta \mathrm{H}-$, and PNMT-immunoreactive) cells of the adrenal organ of vertebrates. Gen Comp Endocrinol 1993;90:251-65.
[244] Rieker S, Fischer-Colbrie R, Eiden L, Winkler H. Phylogenetic distribution of peptides related to chromogranins A and B. J Neurochem 1988;50:1066-73.

[245] Ristori MT, Laurent P. Plasma catecholamines and glucose during moderate exercise in the trout: comparisons with bursts of violent activity. J Exp Biol 1985;44:247-53.

[246] Ristori MT, Laurent P. Plasma catecholamines in rainbow trout (Salmo gairdneri) during hypoxia. Exp Biol 1989;48:28590 .

[247] Root RW. The respiratory function of the blood of marine fishes. Biol Bull 1931;61:427-52.

[248] Ross ME, Evinger MJ, Hyman SE, Carroll JM, Mucke L, Comb M, Reis DJ, Joh TH, Goodman HM. Identification of a functional glucocorticoid response element in the phenylethanolamine $N$-methyltransferase promoter using fusion genes introduced into chromaffin cells in primary culture. J Neurosci 1990;10:520-30.

[249] Scheuermann DW. Untersuchungen hinsichtlich der Innervation des Sinus venosus und des Aurikels von Protopterus annectens. Acta Morphol Neerl Scand 1979;17:231-2.

[250] Scheuermann DW. Comparative morphology, cytochemistry and innervation of chromaffin tissue in vertebrates. $\mathbf{J}$ Anat 1993; 183:327-42.

[251] Schreck CB. Physiological, behavioral, and performance indicators of stress. Am Fish Soc Symp 1990;8:29-37.

[252] Shepard DM, West GB. Differentiation of chromaffin cells. J Pharm Pharmacol 1953;5:216.

[253] Shepard DM, West GB, Erspamer V. Chromaffin bodies of various species of dogfish. Nature 1953;172:509.

[254] Sigaffos J, Chestnut WG, Merrill BN, Taylor LCE, Diliberto EJ, Viveros $\mathrm{OH}$. Novel peptides from adrenomedullary chromaffin vesicles. J Anat 1993;183:253-64.

[255] Spector S, Gordon R, Sjoerdsma A, Udenfriend S. Endproduct inhibition of tyrosine hydroxylase as a possible mechanism for regulation of norepinephrine synthesis. Mol Pharmacol 1967;3:549-55.

[256] Spry DJ, Wood CM. Zinc influx across the isolated, perfused head preparation of the rainbow trout (Salmo gairdneri) in hard and soft water. Can J Fish Aquat Sci 1988;45:2206-15.

[257] Stabrovskii EM. Adrenaline and noradrenaline in organs of the carp, Cyprinus carpio, at rest and under functional stresses. J Evol Biochem Physiol 1968;4:337-41.

[258] Stachowiak MK, Jiang HK, Poisner AM, Tuominen RK, Hong JS. Short and long term regulation of catecholamine biosynthetic enzymes by angiotensin in cultured adrenal medullary cells. J Biol Chem 1990;265:4694-702.

[259] Storch V, Juario JV. The effect of starvation and subsequent feeding on hepatocytes of Chanos chanos (Forsskal) fingerlings and fry. J Fish Biol 1983;23:95-103.

[260] Sumpter JP, Dye HM, Benfey TJ. The effects of stress on plasma ACTH, $\alpha$-MSH, and cortisol levels in salmonid fishes. Gen Comp Endocrinol 1986;62:377-85.

[261] Sumpter JP, Le Bail PY, Pickering AD, Pottinger TG, Carragher JF. The effect of starvation on growth and plasma growth hormone concentrations of rainbow trout, Oncorhynchus mykiss. Gen Comp Endocrinol 1991;83:94-102.

[262] Swilem AMF, Hawthorne JN. Catecholamine secretion by perfused bovine adrenal medulla in response to nicotinic activation is inhibited by muscarinic receptors. Biochem Pharmacol 1983;32:3873-4.

[263] Tang Y, Boutilier RG. Correlation between catecholamine release and degree of acidotic stress in rainbow trout, Salmo gairdneri. Am J Physiol 1988;255:R395-9.

[264] Thoenen H, Mueller RA, Axelrod J. Transsynaptic induction of adrenal tyrosine hydroxylase. J Pharm Exp Ther 1969;169:24954 . 
[265] Thoenen H, Mueller RA, Axelrod J. Increased tyrosine hydroxylase activity after drug-induced alteration of sympathetic transmission. Nature 1969;221:1264.

[266] Thomas S, Fievet B, Claireaux G, Motais R. Adaptive respiratory responses of trout to acute hypoxia: I Effects of water ionic composition on blood acid-base status response and gill morphology. Respir Physiol 1988;74:77-90.

[267] Thomas S, Perry SF. Control and consequences of adrenergic activation of red blood cell $\mathrm{Na}^{+} / \mathrm{H}^{+}$exchange on blood oxygen and carbon dioxide transport in fish. J Exp Zool 1992;263:160-75.

[268] Thomas S, Perry SF, Pennec Y, Maxime V. Metabolic alkalosis and the response of the trout, Salmo fario, to acute severe hypoxia. Respir Physiol 1992;87:91-104.

[269] Uceda G, Artelejo A R, Lopez M G, Abad F, Neher E, Garcia AG. $\mathrm{Ca}^{2+}$-activated $\mathrm{K}^{+}$channels modulate muscarinic secretion in cat chromaffin cells. J Physiol 1992;454:213-30.

[270] Ungar A, Phillips JH. Regulation of the adrenal medulla. Physiol Rev 1983;63:787-843.

[271] Ungell AL. Accumulation of intra-arterially administered $\left[{ }^{3} \mathrm{H}\right]$ adrenaline and $\left[{ }^{3} \mathrm{H}\right]$ noradrenaline in various tissues of the Atlantic cod, Gadus morhua. Comp Biochem Physiol C 1985;81:25-8.

[272] Ungell AL. Uptake of $\left[{ }^{3} \mathrm{H}\right]$ adrenaline and $\left[{ }^{3} \mathrm{H}\right]$ noradrenaline into neuronal and extraneuronal compartments in the perfused gas gland of the swimbladder of the Atlantic cod, Gadus morhua. Comp Biochem Physiol C 1985;64:137-41.

[273] Unsicker K. The chromaffin cell: paradigm in cell, developmental and growth factor biology. J Anat 1993;183:207-21.

[274] Van Dijk PLM, Wood CM. The effect of $\beta$-adrenergic blockade on the recovery process after strenuous exercise in the rainbow trout, Salmo gairdneri Richardson. J Fish Biol 1988:32:557-70.

[275] Van Leeuwen CJ, Helder T, Seinen W. Aquatic toxicological aspects of dithiocarbamates and related compounds: IV Teratogenicity and histopathology in rainbow trout (Salmo gairdneri ). Aquat Toxicol 1986;9:147-59.

[276] Vatta MS, Bianciotti LG, Fernandez BE. Influence of atrial natriuretic factor on uptake, intracellular distribution, and release of norepinephrine in rat adrenal medulla. Can J Physiol Pharmacol 1993;71:195-200.

[277] Verhofstad AAJ. Kinetics of adrenal medullary cells. J Anat 1993;183:315-26.

[278] Voigt JP, Kaufmann G, Hirsch B, Leonhardt S, Jarry H, Oehme P, Wuttke W. In vivo-effect of intraadrenal nicotine and substance $\mathrm{P}$ application on rat adrenal medullary catecholamine secretion. Exp Clin Endocrinol 1994;102:111-7.

[279] Vijayan MM, Leatherland JF. Cortisol-induced changes in plasma glucose, protein, and thyroid hormone levels and liver glycogen content of coho salmon (Oncorhynchus kisutch Walbaum). Can J Zool 1989;67:2746-50.

[280] Vijayan MM, Moon TW. Acute handling stress alters hepatic glycogen metabolism in food-deprived rainbow trout (Oncorhynchus mykiss). Can J Fish Aquat Sci 1992;49:2260-6.

[281] von Euler US, Fänge R. Catecholamines in nerves and organs of Myxine glutinosa, Squalus acanthias, and Gadus callarias. Gen Comp Endocrinol 1961;1:191-4.

[282] Wahlqvist I. Branchial vascular effects of catecholamines released from the head kidney, Gadus morhua. Mol Physiol 1981;1:235-41

[283] Wahlqvist I, Nilsson S. Adrenergic control of the cardio-vascular system of the Atlantic cod, Gadus morhua during 'stress'. J Comp Physiol B 1980;137:145-50.

[284] Wakade TD, Blank MA, Malhotra RK, Pourcho R, Wakade AR. The peptide VIP is a neurotransmitter in rat adrenal medulla: Physiological role in controlling catecholamine secretion. J Physiol 1991;444:349-62.
[285] Watanabe T, Masuo Y, Matsumoto H, Suzuki N, Ohtaki T, Masuda Y, Kitada C, Tsuda M, Fujino M. Pituitary adenylate cyclase activating polypeptide provokes cultured rat chromaffin cells to secrete adrenaline. Biochem Biophys Res Commun 1992;182:403-11.

[286] Watanabe T, Shimamoto N, Takanashi A, Fujino M. PACAP stimulates catecholamine release from adrenal medulla: a novel noncholinergic secretagogue. Am J Physiol 1995;269:E903-9.

[287] Weber RE, Jensen FB. Functional adaptations in haemoglobins from ectothermic vertebrates. Annu Rev Physiol 1988;50:16179.

[288] Weber RE, Wood SC, Lomholt JP. Temperature acclimation and oxygen-binding properties of blood and multiple haemoglobins of rainbow trout. J Exp Biol 1976;65:333-45.

[289] Weinshilboum R, Axelrod J. Dopamine- $\beta$-hydroxylase activity in the rat after hypophysectomy. Endocrinology 1970;87:894-9.

[290] Wessels-Reiker M, Haycock JW, Howlett AC, Strong R. Vasoactive intestinal polypeptide induces tyrosine hydroxylase in PC12 cells. J Biol Chem 1991;266:9347-50.

[291] Wan DCC, Livett BG. Induction of phenylethanolamine $N$ methyltransferase mRNA expression by glucocorticoids in cultured bovine adrenal chromaffin cells. Eur J Pharmacol 1989;172:107-15.

[292] Wilson RW, Egginton S. Assessment of maximum sustainable swimming performance in rainbow trout (Oncorhynchus mykiss). J Exp Biol 1994;192:299-305.

[293] Winkler H. The adrenal chromaffin granule: a model for large dense core vesicles of endocrine and nervous tissue. J Anat 1993; 183:237-52.

[294] Wood CM. Acid-base and ion balance, metabolism, and their interactions, after exhaustive exercise in fish. J Exp Biol 1991;160:285-308.

[295] Wood $\mathrm{CM} . \mathrm{HCO}_{3}$-dehydration by the blood of rainbow trout following exhaustive exercise. Respir Physiol 1994;98:305-18.

[296] Wood CM, Munger RS. Carbonic anhydrase injection provides evidence for the role of blood acid-base status in stimulating ventilation after exhaustive exercise in rainbow trout. J Exp Biol 1994;194:225-53.

[297] Wood CM, Walsh PJ, Thomas S, Perry SF. Control of red blood cell metabolism in rainbow trout (Oncorhynchus mykiss) after exhaustive exercise. J Exp Biol 1990;154:491-507.

[298] Wright A, Jones IC. Chromaffin tissue in the lizard adrenal gland. Nature 1955;175:1001-2.

[299] Wright A, Jones IC. The adrenal gland of lizards and snakes. J Endocrinol 1957;15:83-99.

[300] Wurtman RJ, Axelrod J. Control of enzymatic synthesis of adrenaline in the adrenal medulla by adrenal cortical steroids. $\mathbf{J}$ Biol Chem 1966;241:2301-5.

[301] Wurtman RJ, Noble EP, Axelrod J. Inhibition of enzymatic synthesis of epinephrine by low doses of glucocorticoids. Endocrinology 1967;80:825-8.

[302] Yamaguchi N. In vivo evidence for adrenal catecholamine release mediated by nonnicotinic mechanism: local medullary effect of VIP. Am J Physiol 1993;265:R766-71.

[303] Yamamoto KR. Steroid receptor regulated transcription of specific genes and gene networks. Ann Rev Genet 1985;19:20952.

[304] Ye X, Randall DJ, He X. The effect of acid water on oxygen consumption,circulating catecholamines and blood ionic and acid-base status in rainbow trout Salmo gairdneri, (Richardson). Fish Physiol Biochem 1991;9:23-30.

[305] Yoakim EG, Grizzle JM. Histological, histochemical and ultrastructural studies on the interrenal and chromaffin cells of the fathead minnow, Pimephales promelas, Rafinesque. J Fish Biol 1980;17:477-94. 
[306] Yon L, Chartrel N, Feuilloley M, De Marchis S, Fournier A, De Rijk E, Pelletier G, Roubos E, Vaudry H. Pituitary adenylate cyclase-activating polypeptide stimulates both adrenocortical cells and chromaffin cells in the frog adrenal gland. Endocrinology 1994;135:274958.
[307] Youson JH. Fine structure of granulated cells in the posterior cardinal and renal veins of Amia calva L. Can J Zool 1976;54:843-51.

[308] Zigmond RE. Biochemical consequences of synaptic stimulation: the regulation of tyrosine hydroxylase activity by multiple transmitters. Trends Neurosci 1985;8:63-9. 